\title{
Tellurium and Selenium Mineralogy of Gold Deposits in Northern Fennoscandia
}

\author{
Arkadii A. Kalinin (D) \\ Kola Science Center, Geological Institute, Russian Academy of Science, 184200 Apatity, Russia; \\ kalinin@geoksc.apatity.ru; Tel.: +7-921-663-68-36
}

check for updates

Citation: Kalinin, A.A. Tellurium and Selenium Mineralogy of Gold Deposits in Northern Fennoscandia. Minerals 2021, 11, 574. https:// doi.org/10.3390/min11060574

Academic Editors: Vasilios Melfos and Panagiotis Voudouris

Received: 5 May 2021

Accepted: 26 May 2021

Published: 27 May 2021

Publisher's Note: MDPI stays neutral with regard to jurisdictional claims in published maps and institutional affiliations.

Copyright: (C) 2021 by the author. Licensee MDPI, Basel, Switzerland. This article is an open access article distributed under the terms and conditions of the Creative Commons Attribution (CC BY) license (https:// creativecommons.org/licenses/by/ $4.0 /)$.

\begin{abstract}
Mineralization of Te and Se was found in gold deposits and uranium occurrences, located in the Paleoproterozoic greenstone belts in Northern Fennoscandia. These deposits are of different genesis, but all of them formed at the late stages of the Svecofennian orogeny, and they have common geochemical association of metals $\mathrm{Au}, \mathrm{Cu}, \mathrm{Co}, \mathrm{U}, \mathrm{Bi}, \mathrm{Te}$, and Se. The prevalent Te minerals are $\mathrm{Ni}$ and $\mathrm{Fe}$ tellurides melonite and frohbergite, and $\mathrm{Pb}$ telluride altaite. Bismuth tellurides were detected in many deposits in the region, but usually not more than in two-three grains. The main selenide in the studied deposits is clausthalite. The most diversified selenium mineralization (clausthalite, klockmannite, kawazulite, skippenite, poubaite) was discovered in the deposits, located in the Russian part of the Salla-Kuolajarvi belt. Consecutive change of sulfides by tellurides, then by selenotellurides and later by selenides, indicates increase of selenium fugacity, $f \mathrm{Se}_{2}$, in relation to $f \mathrm{Te}_{2}$ and to $f S_{2}$ in the mineralizing fluids. Gold-, selenium-, and tellutium-rich fluids are potentially linked with the post-Svecofennian thermal event and intrusion of post-orogenic granites (1.79-1.75 Ga) in the Salla-Kuolajarvi and Perapohja belts. Study of fluid inclusions in quartz from the deposits in the Salla-Kuolajarvi belt showed that the fluids were high-temperature $\left(240-300{ }^{\circ} \mathrm{C}\right)$ with high salinity (up to $26 \% \mathrm{NaCl}$-eq.). Composition of all studied selenotellurides, kawazulite-skippenite, and poubaite varies significantly in $\mathrm{Se} / \mathrm{Te}$ ratio and in $\mathrm{Pb}$ content. Skippenite and kawazulite show the full range of Se-Te isomorphism. Ni-Co and Co-Fe substitution plays an important role in melonite and mattagamite: high cobalt was detected in nickel telluride in the Juomasuo and Konttiaho, and mattagamites from Ozernoe and Juomasuo contain significant Fe. In the Ozernoe uranium occurrence, the main mineral-concentrator of selenium is molybdenite, which contains up to $16 \mathrm{wt} . \%$ of Se in the marginal parts of the grains. The molybdenite is rich in Re (up to $1.2 \mathrm{wt} . \%$ ), and the impurity of Re is irregularly distributed in molybdenite flakes and spherulites.
\end{abstract}

Keywords: Fennoscandian Shield; Salla-Koulajarvi belt; Mayskoe gold deposit; Ozernoe uranium occurrence; kawazulite; skippenite; molybdenite

\section{Introduction}

Findings of selenium and tellurium minerals are not often, but are of big interest, because they may indicate precious metals' mineralization: Se and Te often associate with gold, silver, platinum, and palladium mineralization and can form chemical compounds with these metals.

Gold deposits (including those where gold is a by-product) in the Northern part of the Fennoscandian Shield contain diverse Te (with minor Se) mineralization, which was detected in the Lapland greenstone belt (Saattopora, Pahtavaara), Kuusamo-Panajarvi belt (Juomasuo, Hangaslampi, Sivakkaharju, Konttiaho), and Peräpohja belt (Rompas) [1-4] (Figure 1). These gold deposits are of different genetic type, but all of them contain $\mathrm{Cu}, \mathrm{Co}$, $\mathrm{Bi}, \mathrm{Te}$, and $\mathrm{U}$ mineralization. 

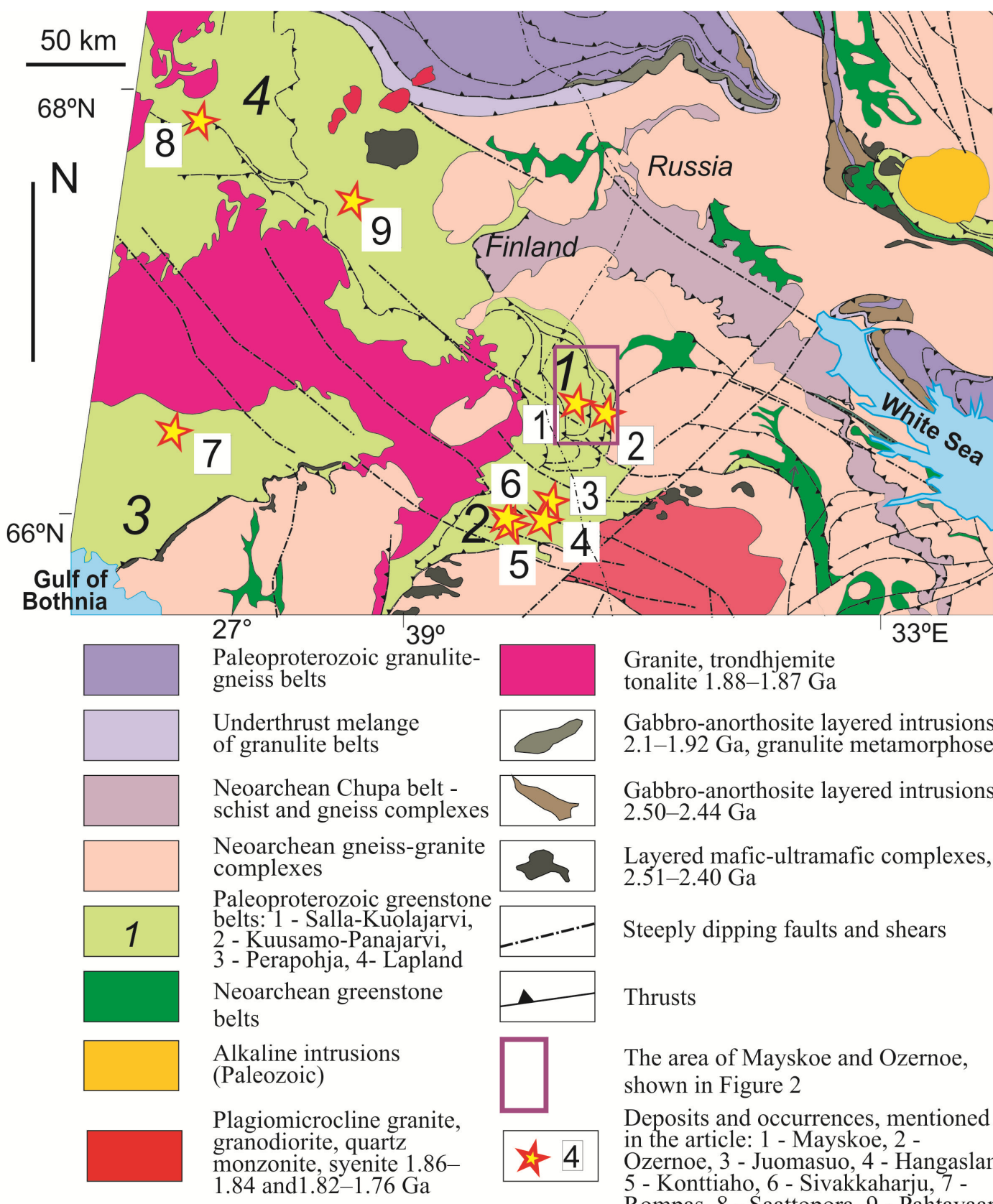

Granite, trondhjemite tonalite $1.88-1.87 \mathrm{Ga}$

Gabbro-anorthosite layered intrusions 2.1-1.92 Ga, granulite metamorphosed

Gabbro-anorthosite layered intrusions $2.50-2.44 \mathrm{Ga}$

Layered mafic-ultramafic complexes, $2.51-2.40 \mathrm{Ga}$

Steeply dipping faults and shears

Thrusts

The area of Mayskoe and Ozernoe, shown in Figure 2

Deposits and occurrences, mentioned in the article: 1 - Mayskoe, 2 -

Ozernoe, 3 - Juomasuo, 4 - Hangaslampi,

5 - Konttiaho, 6 - Sivakkaharju, 7 -

Rompas, 8 - Saattopora, 9 - Pahtavaara

Figure 1. Gold deposits and occurrences with Se-Te mineralization in the northern part of the Fennoscandian Shield (adapted after [5]).

Data on Te and Se mineralization in the Finnish Lapland deposits, presented in this article, are taken from published papers and Internet resources with open access.

In the Russian part of the Salla-Kuolajarvi belt, gold deposits and occurrences with Te and Se mineralization are known as well. It is minor gold deposit Mayskoe, the only deposit ever mined for gold in the Kola region [6-8], and uranium gold-bearing occurrence Ozernoe (Figure 1) $[9,10]$. These deposits differ in diverse Te-Se mineralization (total more than $20 \mathrm{Te}$ and Se mineral phases), and are richer in selenium mineralization than the deposits in Finland.

\section{Materials and Methods}

Investigations of wall-rock alteration, metasomatic zoning, and determination of preore, syn-ore, and post-ore mineral assemblages in altered rocks were based on the study 
of rocks picked in outcrops and trenches, and considering mineral relations in thin and polished sections.

Tellurium and selenium mineralization of the Ozernoe occurrence were studied in samples (1.5-10 kg) collected by the author in the outcrops and trenches during 2011-2012.

The Mayskoe gold deposit was mined in 1998-2000 (total gold output $51 \mathrm{~kg}$ ), then the mine was flooded and abandoned. The specimens for investigation of mineral composition were collected here in 2016 from the ore storage. The heavy minerals concentrate was panned from the tailings at the deposit, screened, and later separated with bromoform in the laboratory. Non-magnetic and electromagnetic bromoform-heavy fractions of $-0.5 \mathrm{~mm}$ were studied in epoxy polished sections.

Mineral composition of the ores was studied in polished sections with the reflected light microscope Axioplan 2 Imaging (Karl Zeiss, Jena, Germany), and with the electron microscope LEO-1450 (Karl Zeiss, Jena, Germany) in the Geological Institute of the Kola Science Center.

Semi-quantitative estimation of composition for preliminary identification of mineral species was performed with the energy-dispersive system (EDS) Bruker XFlash-5010 (BRUKER, Ettlingen, Germany). Microprobe analysis (MS-46, CAMECA, Gennevilliers Cedex, France), accelerating voltage $22 \mathrm{kV}$, beam current 30-40 nA, standards (analytical lines; detection limit, wt.\%): $\mathrm{Fe}_{10} \mathrm{~S}_{11}(\mathrm{FeK} \alpha ; 0.01$ and $\mathrm{SK} \alpha ; 0.05), \mathrm{Bi}_{2} \mathrm{Se}_{3}(\mathrm{BiM} \alpha ; 0.1$ and $\mathrm{SeK} \alpha ; 0.05), \operatorname{LiNd}\left(\mathrm{MoO}_{4}\right)_{2}(\mathrm{MoL} \alpha ; 0.1), \mathrm{PbS}(\mathrm{PbM} \alpha ; 0.1)$, pure metals $\mathrm{Co}(\mathrm{CoK} \alpha ; 0.01)$, $\mathrm{Ni}(\mathrm{NiK} \alpha ; 0.01), \mathrm{Cu}(\mathrm{CuK} \alpha ; 0.01), \operatorname{Pd}(\mathrm{PdL} \alpha ; 0.05), \mathrm{Ag}(\mathrm{AgL} \alpha ; 0.05), \mathrm{Te}(\mathrm{TeL} \alpha ; 0.05), \operatorname{Re}$ $(\operatorname{ReL} \alpha ; 0.05), \mathrm{Au}(\mathrm{AuL} \alpha ; 0.05)$, was performed for grains larger than $20 \mu \mathrm{m}$ (analysts Ye. Savchenko and A.Telezhkin). Beam size was $2-10 \mu \mathrm{m}$, depending on stability of the matter under the beam current. Measurement time was $10 \mathrm{~s}$ for major elements, $20 \mathrm{~s}$ for minor elements, and $10 \mathrm{~s}$ for background measurements. The results of $4-5$ measurements for each element were averaged.

The verification of some mineral phases and identification of molybdenite polytype were performed with X-ray analysis in the Geological Institute of the Kola Science Center (analyst E. Selivanova). Visually homogenous material of $50 \times 10 \mu \mathrm{m}$ or more in size was extracted from the polished sections and examined with the X-ray powder diffraction (Debye-Scherer) on URS-1 (Burevestnik, Irkutsk, Russia) operated at $40 \mathrm{kV}$ and $16 \mathrm{~mA}$, with an RKU114.7 mm camera and FeK $\alpha$ radiation.

\section{Results}

The Salla-Kuolajarvi belt is a member of the Lapland-Karelian Paleoproterozoic greenschist belt system. The belt is of asymmetric structure: the eastern zone (the Russian part) has a simple cross-section with rock sequences dipping west at an angle of $70^{\circ}$ (in the flank) to $10^{\circ}$ (in the center of the belt). The western part of the belt (in Finland) is represented by a set of granitized tectonic blocks, with each block having its own structure [11].

Volcanic-sedimentary rocks in the Russian part formed in Jatulian $(2.3-2.1 \mathrm{Ga})$ and Ludikovian (2.1-1.92 Ga), while older rocks (Sumian-Sariolian, 2.5-2.3 Ga) are known only in the neighboring Kuusamo-Panajarvi belt [11].

\subsection{The Mayskoe Gold Deposit}

The small deposit of Mayskoe (\#1 in Figure 1) is located in the central part of the SallaKuolajarvi belt. Quartz veins in the deposit are hosted in metavolcanics of the Apajarvi Formation (basalt, andesite, and mafic tuffs), intruded by dolerite dykes and ultramafic sills (Figure 2). The dykes are controlled by northeast trending faults and form two sub-parallel bodies, dipping northwest at an angle of $60-80^{\circ}[8,12]$. The faults are $5-10 \mathrm{~m}$ thick zones of schistosity, foliation, and jointing. The same northeast trending faults control zones of pre-vein metasomatic alteration and location of two gold-bearing quartz veins, i.e., the faults play the role of ore-hosting tectonic structures [8]. The metal association of the deposit can be described as Ag- $\mathrm{Cu}-\mathrm{Pb}-\mathrm{Au}(\mathrm{Zn}-\mathrm{Co}-\mathrm{Te}-\mathrm{W})$ [5]. More details on the geology of the Mayskoe deposit are provided in $[8,13]$. 


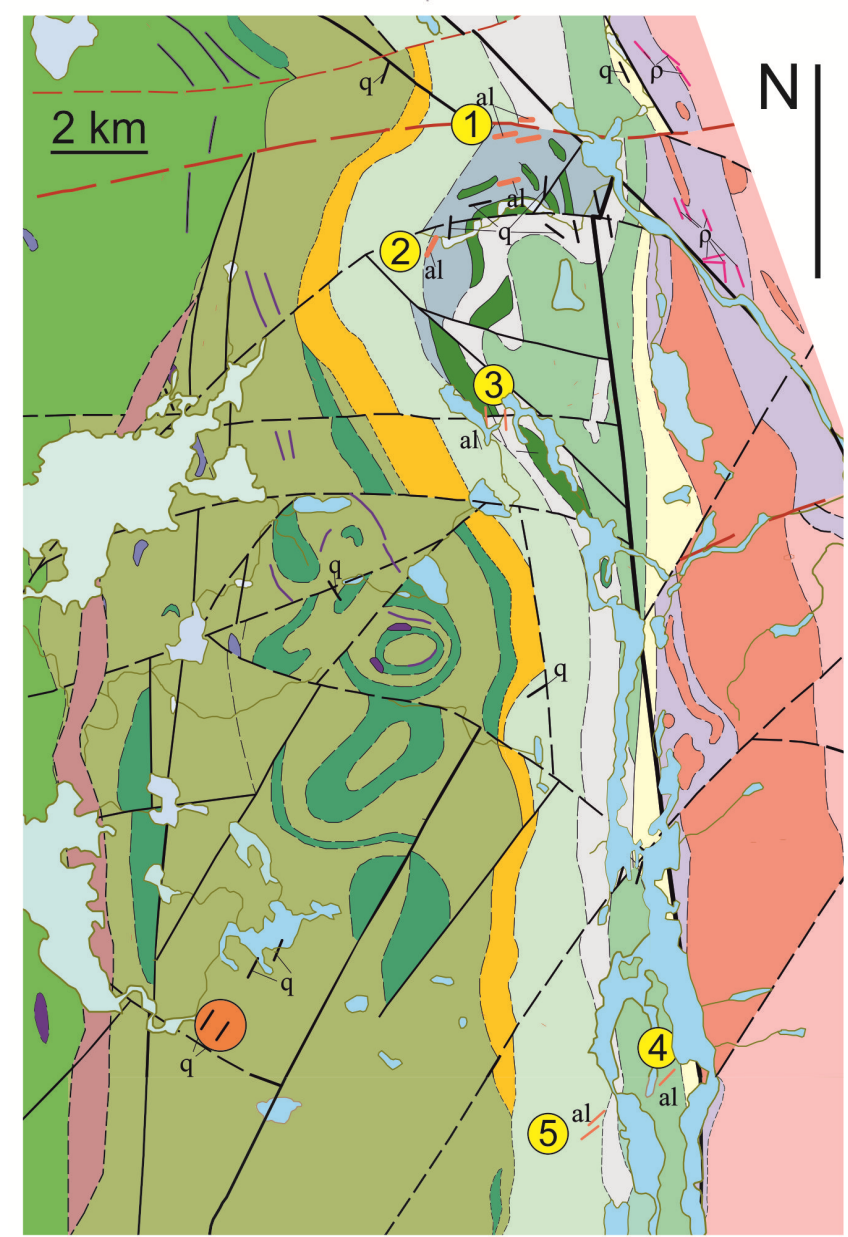

Faults:

activizated in

the Paleozoic

the main faults

other plausible faults

other inferred faults

Mayskoe gold deposit
Paleoproterozoic:

Sotkoivinskaya unit

(metabasalt, metamandelstein)

Kailarskaya unit (quartz

sandstone, tuffaceous sandstone, dolomite)

Apajarvinskaya unit

(metabasalt, metamandelstein)

Noukajarvinskaya unit (quartz

sandstone, polymictic conglome-

rate, quartz-biotite-epidote schist)

Kyasijarvinskaya unit

(metabasalt, metaandesite),

Kuonajarvinskaya unit (flysch

rocks - siltstone, greywacke,

dolomite, carbonaceous schist)

Jurhyamyajarvinskaya unit

(quartz sandstone, dolomite,

limestone, phyllite)

Niluttijarvinskaya unit

(plagioschist after metabasalt

and metaandesite, amphibolite)

Nivajarvinskaya unit (quartzite, quartz sandstone, phyllite, conglomerate)

Neorchean:

Chelozerskaya unit (schistose amphibolite, amphibole-biotitegarnet and biotite-staurolite schists, micaceous schist, quartzite) Belomorian metamorphic complex (granitizated plagiogneiss and amphibolite)

Intrusive complexes:

Gabbro-peridotite, gabbro, pyroxenite of the Kuolajarvi complex

Peridotite, pyroxene

olivinite of the

Kuolajarvi complex

Leucocratic gabbro of the Panajarvi complex

Gneiss-granite,

migmatitic granite

Figure 2. Schematic geological map of the eastern part of the Salla-Kuolajarvi belt (adapted after [5]).

Gold in the veins is distributed unevenly. Ore shoots are localized in those parts of the veins which are of complicated morphology, with xenoliths, intensely jointed, and with granular quartz. Ore shoots are 20-30 m in vertical section (80-110 m long on the surface), and pitch $15-20^{\circ}$ northeast.

Nested and veinlet sulfide mineralization is located mainly close to the vein selvages, or at the contact with xenoliths. Sulfides and native metals make up less than 1 vol.\% of the vein mass. The veinlets are less than $1 \mathrm{~cm}$ thick and 10-20 cm long. Sulfide aggregates may be up to a few $\mathrm{cm}$ in size. Ore mineral assemblage includes (in the order of quantity decrease) chalcopyrite as the main mineral, pyrrhotite, sphalerite, galena, pyrite, cobaltite, native gold, sporadic marcasite, gersdorffite, mackinawite, bornite, cubanite, cobaltian pentlandite, violarite, siegenite, altaite, tsumoite, tellurobismuthite, clausthalite, molybdenite, 
klockmannite, costibite, hessite, native silver, arsenopyrite, covellite, argentopentlandite, stuetzite, volynskite, and native tellurium $[6-8,14,15]$. Greenockite, tetradymite, bismuthite, vavřínite, glaucodot, unidentified Ni telluride, and Au telluride are mentioned in [14], but no microprobe or X-ray data, photo, or description of these mineral phases was published. The primary oxide minerals are rutile, ilmenite, magnetite, and scheelite.

Visible gold was detected in fractures in quartz, often in intergrowths with galena and sphalerite. Grains of gold are of irregular flattened form, rounded, and hexahedral. The gold fineness is high (900-960) [6-8,14,15]. Se and Te mineralization concentrates in gold-rich parts of the veins.

We see in the polished sections that tellurides associate mainly with galena (Figure 3), and multimineral rucklidgeite-altaite inclusion was found in pyrrhotite only in one case. However, Gavrilenko [7] described the occurrence of altaite along fractures in the early sulfides, chalcopyrite and pyrrhotite, as well.
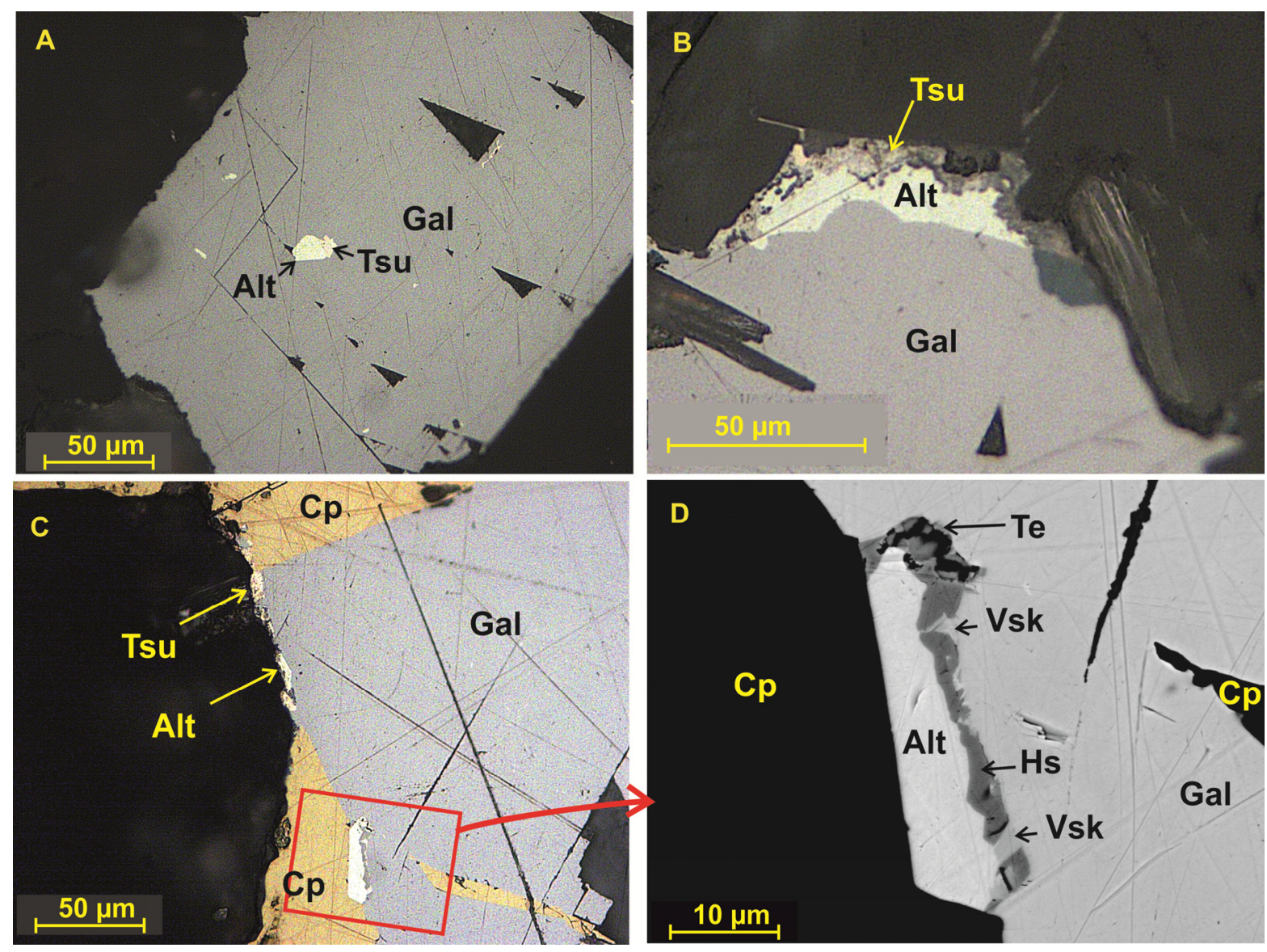

Figure 3. Tellurides from the Mayskoe deposit. (A-C)Polished sections' photos, plane polarized light, (D) back-scattered electron image (BSE). Alt—altaite, Cp-chalcopyrite, Gal-galena, Hs-hessite, Te-native tellurium, Tsu—tsumoite, Vsk-volynskite.

Altaite forms inclusions up to $15 \mu \mathrm{m}$ in size (Figure 3), and more often these inclusions are located in the marginal parts of galena grains, at the contact with chalcopyrite and quartz. Bismuth and silver tellurides tsumoite, stuetzite, volynskite, and native tellurium formed along the cracks at the altaite-galena boundary, and the size of tiny telluride grains is not more than a few micrometers (Figure 3).

$\mathrm{Pb}$ and $\mathrm{Cu}$ selenides clausthalite and klockmannite were first described in the deposit by Gavrilenko [6,7]. These minerals occur as prismatic or roundish inclusions up to $30 \mu \mathrm{m}$ in size in chalcopyrite, pyrrhotite, and sphalerite. No inclusions of selenides were detected in galena due to Se-S isomorphism: content of Se in galena reaches $10 \mathrm{wt} . \%$. The selenides 
clausthalite and klockmannite contain some Te and S, but sulfur probably originates from the surrounding sulfides.

The sulfide concentrate, panned from the tailings, contains lath-shaped monomineral grains with perfect $\{0001\}$ cleavage, up to $50 \mu \mathrm{m}$ large. These are bismuth tellurides and selenotellurides. We detected rucklidgeite with low content of $\mathrm{Pb}$, poubaites with different $\mathrm{Se} / \mathrm{Te}$ and $\mathrm{Pb} / \mathrm{Bi}$ ratios, a mineral of kawazulite-skippenite series (49\% of skippenite), and an unnamed mineral with chemical composition, corresponding to formulae $\mathrm{Pb}_{2} \mathrm{Bi}_{2}(\mathrm{Se}, \mathrm{S})_{3} \mathrm{Te}_{2}$ (Table 1). All bismuth tellurides and selenotellurides contain significant impurity of $\mathrm{Pb}$.

Table 1. Microprobe data for tellurides and selenides from the Mayskoe.

\begin{tabular}{|c|c|c|c|c|c|c|c|c|c|c|c|}
\hline & 1 & 2 & 3 & 4 & $5 *$ & 6 & 7 & 8 & 9 * & $10 * *$ & $11 * *$ \\
\hline $\mathrm{Fe}, \mathrm{wt} . \%$. & 0.18 & 0.12 & 0.10 & 0.23 & bdl & 0.08 & 0.06 & 0.03 & bdl & 1.03 & 0.99 \\
\hline Cu, wt.\%. & n.a. & n.a. & n.a. & n.a. & n.a. & n.a. & n.a. & 0.03 & n.s. & 41.63 & 41.31 \\
\hline $\mathrm{Pb}$, wt.\%. & 34.93 & 18.80 & 27.44 & 4.63 & 12.58 & 8.86 & 69.54 & 71.19 & 81.35 & 0.49 & 0.52 \\
\hline Ag, wt.\%. & bdl & bdl & bdl & bdl & bdl & bdl & 0.45 & n.a. & 0.04 & 0.60 & 0.51 \\
\hline Bi, wt.\%. & 28.41 & 39.62 & 31.57 & 52.91 & 47.38 & 47.44 & 1.56 & 0.34 & n.a. & n.a. & n.a. \\
\hline $\mathrm{Sb}$, wt. $\%$. & 0.33 & 0.34 & bdl & bdl & n.a. & bdl & bdl & n.a. & n.a. & n.a. & n.a. \\
\hline S, wt.\%. & 0.67 & 0.29 & 0.13 & 0.09 & bdl & 0.07 & 0.68 & 1.18 & 9.91 & 6.44 & 6.26 \\
\hline Se, wt.\%. & 15.92 & 13.52 & 7.19 & 15.86 & 1.01 & 1.09 & 25.30 & 23.35 & 8.25 & 45.33 & 46.76 \\
\hline Te, wt.\%. & 19.14 & 27.03 & 33.48 & 26.24 & 39.21 & 42.78 & 2.61 & 3.21 & 0.49 & 5.42 & 3.97 \\
\hline Total, wt.\%. & 99.58 & 99.71 & 99.90 & 99.95 & 100.18 & 100.32 & 100.18 & 99.33 & 100.04 & 100.94 & 100.32 \\
\hline \multicolumn{12}{|c|}{ Atoms per formula unit } \\
\hline $\mathrm{Fe}$ & 0.04 & 0.02 & 0.02 & 0.03 & & 0.01 & & 0.01 & & 0.02 & 0.02 \\
\hline $\mathrm{Cu}$ & & & & & & & & 0.01 & & 0.80 & 0.79 \\
\hline $\mathrm{Pb}$ & 2.26 & 0.93 & 1.48 & 0.16 & 0.19 & 0.49 & 0.93 & 0.96 & 0.94 & & \\
\hline $\mathrm{Ag}$ & & & & & & & 0.01 & & & 0.01 & 0.01 \\
\hline $\mathrm{Bi}$ & 1.83 & 1.93 & 1.69 & 1.86 & 0.71 & 2.58 & 0.02 & 0.00 & & & \\
\hline $\mathrm{Sb}$ & 0.04 & 0.03 & & & & & & & & & \\
\hline S & 0.28 & 0.09 & 0.05 & 0.02 & & 0.02 & 0.06 & 0.10 & 0.74 & 0.25 & 0.24 \\
\hline Se & 2.71 & 1.75 & 1.02 & 1.47 & 0.04 & 0.16 & 0.89 & 0.83 & 0.25 & 0.70 & 0.72 \\
\hline $\mathrm{Te}$ & 2.01 & 2.16 & 2.94 & 1.51 & 0.96 & 3.82 & 0.06 & 0.07 & 0.01 & 0.05 & 0.04 \\
\hline
\end{tabular}

Notes: bdl = below the detection limit, n.a. = not analyzed. $1-\mathrm{Pb}_{2} \mathrm{Bi}_{2}(\mathrm{Se}, \mathrm{S})_{3} \mathrm{Te}_{2}$, formulae coefficients are calculated for $\mathrm{S}+\mathrm{Se}+\mathrm{Te}=5$; 2,3-poubaite, 4-kawazulite, 5-tsumoite, 6-rucklidgeite, 7, 8-clausthalite, 9-selenian galena, 10, 11-klockmannite. Formulae coefficients of poubaite and rucklidgeite are calculated for $\mathrm{S}+\mathrm{Se}+\mathrm{Te}=4$, of kawazulite, for $\mathrm{S}+\mathrm{Se}+\mathrm{Te}=3$, of selenian galena, clausthalite, and klockmannite for $\mathrm{S}+\mathrm{Se}+\mathrm{Te}=1 .{ }^{*}$ Data from [8], ** data from [6,7].

Clausthalite was detected in the sulfide concentrate as anhedral grains up to $30 \mu \mathrm{m}$ in size, in intergrowths with chalcopyrite and with inclusions $(1-5 \mu \mathrm{m})$ of hessite.

\subsection{The Ozernoe Uranium Occurrence}

A series of albitite occurrences with uranium mineralization is located at the eastern flank of the Salla-Kuolajarvi belt (Figure 2), and some of these occurrences contain Au, Se, $\mathrm{Te}, \mathrm{Mo}$, and Re mineralization. Albitite forms zonal lenses up to $10 \mathrm{~m}$ thick and $10-90 \mathrm{~m}$ long, and the albitite lenses cross general strike of the wall rocks. Albitites may be hosted by different metasedimentary, metavolcanic, or intrusive rocks (Figure 2).

Uranium albitite Ozernoe occurrence is located in the outer part of metamorphosed gabbrodolerite intrusion and hosted by altered amphibolite. A series of albitite lenses is controlled by a shear zone, which crosses the gabbrodolerite intrusion and metavolcanic rocks at an angle of $50^{\circ}$. Transition from the amphibolite to albitite is gradual (Figure 4 ). In the outer part of the zone of alteration, the amphibolite is intensely epidote-altered. Close to the albitite lens, biotite, chlorite, and actinolite replace hornblende in the amphibolite, and the rock is schistose. Albitite makes up the main part of the lenses: albite, chloritealbite, dolomite-albite, dolomite, dolomite-quartz, and quartz zones can be detected, from the border to the center. Dolomite-albite and dolomite rocks, which contain Te-Se mineralization, form veinlets up to $20 \mathrm{~cm}$ thick (Figure 4), or segregations of irregular form 
in albitite, and are usually separated from the albitite by a thin (1-2 mm), discontinuous, dark-colored chlorite-biotite seam, which is notably rich in uraninite and brannerite.
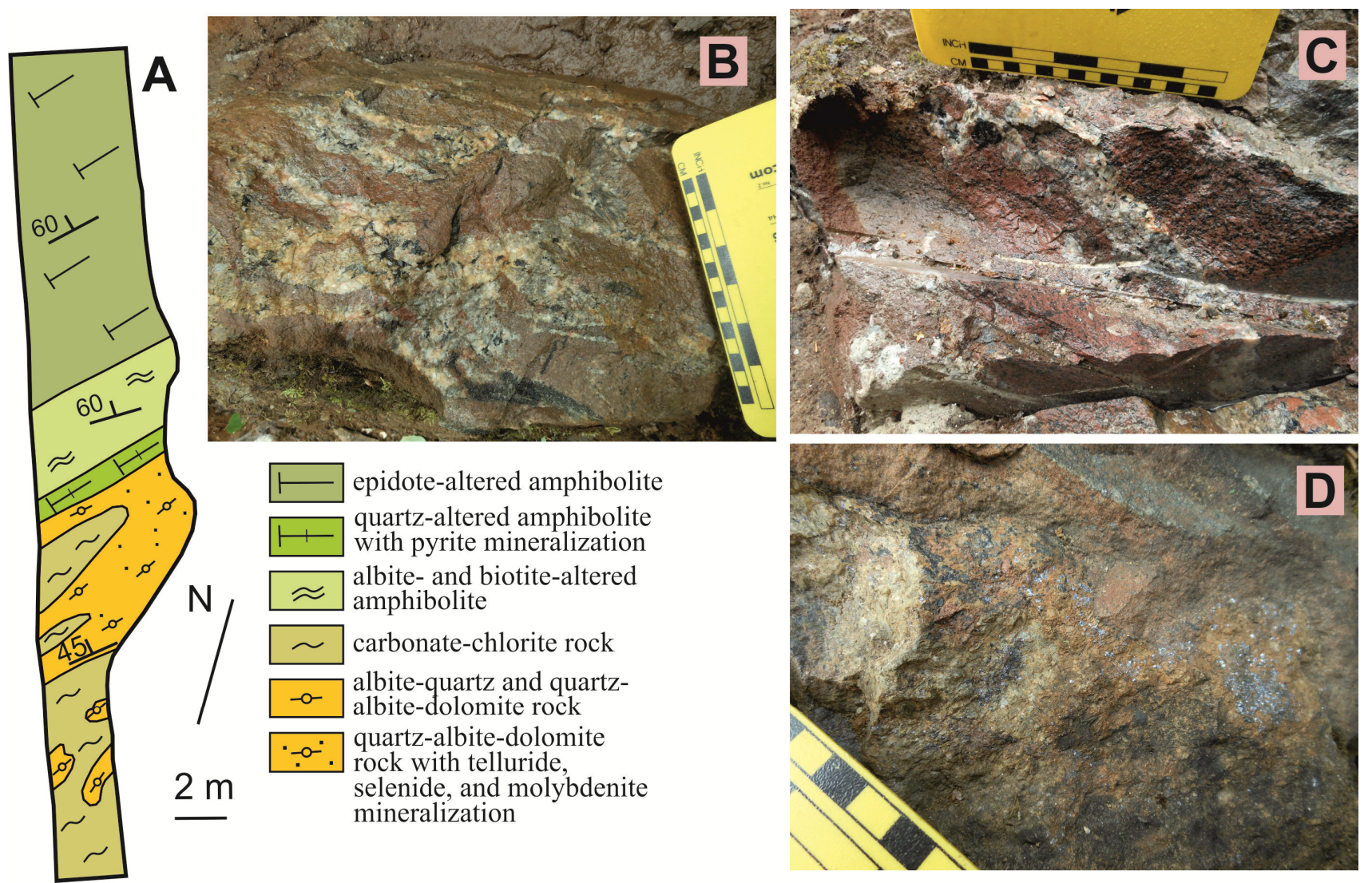

Figure 4. (A) Trench bed logging in the Ozernoe occurrence [5], (B,C) dolomite-quartz veinlets in albitite, (C) a veinlet with rich Te-Se mineralization, and (D) molybdenite (gray) mineralization in albitite.

Albitite and altered amphibolite contain disseminated, nested-disseminated, or veinletdisseminated sulfide mineralization. The main sulfide minerals in altered amphibolite are pyrite and chalcopyrite, while oxide minerals are ilmenite and magnetite. In albitite, rutile and hematite form instead of ilmenite and magnetite. The main sulfides are pyrite, chalcopyrite, molybdenite, and marcasite. Uraninite and brannerite are the prevalent uranium minerals.

Sulfide mineralization in dolomite-albite and dolomite rocks is much more diversified. Content of molybdenite, uraninite, and brannerite increases significantly, tellurides, selenotellurides, selenides, native gold, and tellurium appear in carbonate-albite rocks.

Melonite is the most abundant telluride. It forms lath-shaped or anhedral grains up to $2 \mathrm{~mm}$ large in dolomite, and fills cracks or forms chains of tiny grains along cleavage in the carbonate. Tiny irregular grains of melonite occur at the boundary of uraninite with gangue minerals. Melonite forms inclusions and develops along cleavage in molybdenite. Intergrowths of melonite with other tellurides are rare, but replacement of melonite by altaite is common. More often, we can see replacement of melonite by clausthalite (Figures 5 and 6). Large melonite grains have internal domains (Figure 5), and the domains vary in orientation and differ in selenium content, from 0.2 to $2.2 \mathrm{wt} . \%$ Se. Other impurities in melonite are $\mathrm{Fe}, \mathrm{Co}, \mathrm{Pd}$, and $\mathrm{Pb}$ (Table 2). 

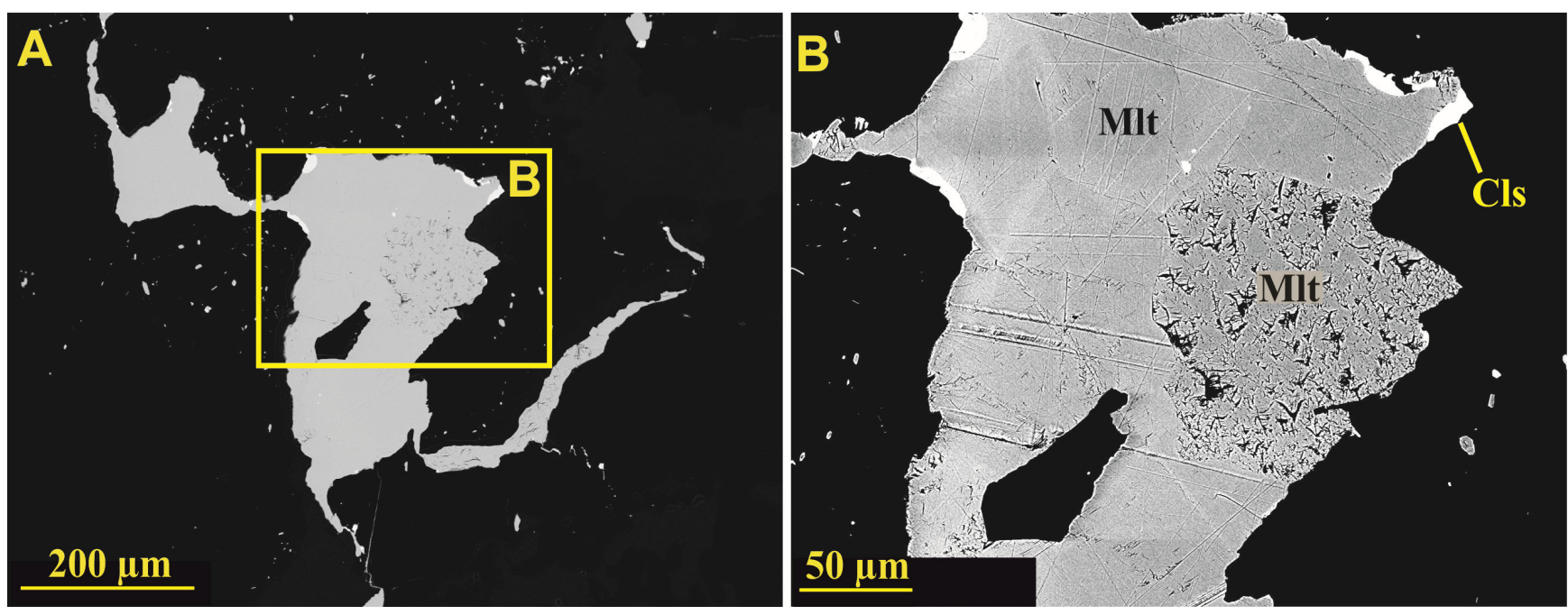

Figure 5. Block structure in melonite. The melonite is replaced by clausthalite in the outer part of the grain. BSE images. (A) general view, (B) detailed area. Cls—clausthalite, Mlt-melonite.
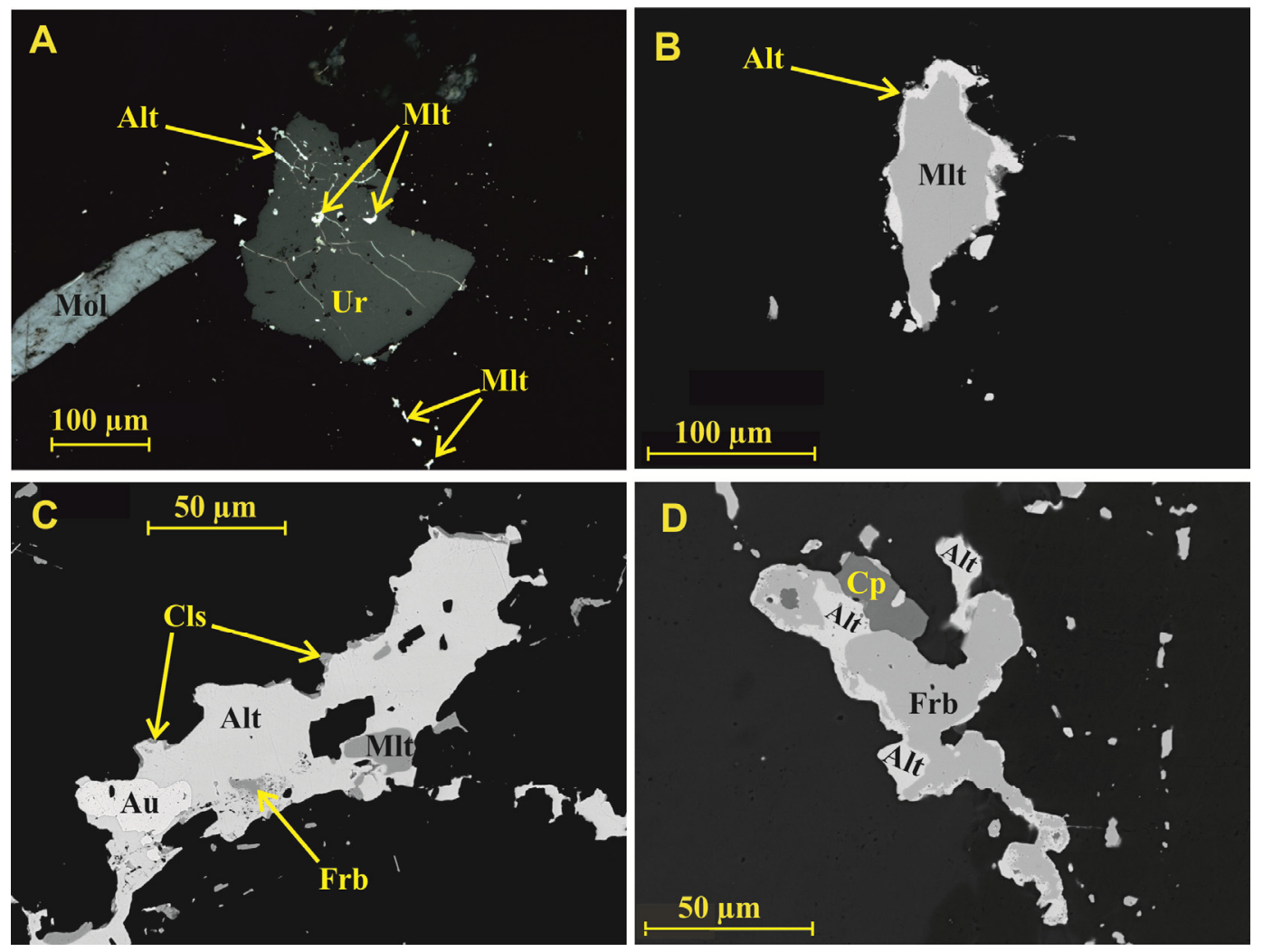

Figure 6. Tellurides in the Ozernoe occurrence. (A) Altaite and melonite along cracks in uraninite and dolomite, (B) altaite rim around melonite grain, $(\mathbf{C})$ native gold in altaite with inclusions of melonite and frohbergite, (D) replacement of frohbergite by altaite. (A) Polished section photo, plane polarized light, (B-D) back-scattered electron images (BSE). Alt—altaite, Au—native gold, Cls—clausthalite, $\mathrm{Cp}$-chalcopyrite, Frb—frohbergite, Mlt—melonite, Mol—molybdenite, Ur-uraninite. 
Table 2. Microprobe data for Te and Se minerals from the Ozernoe.



* Estimation of composition with EDS analysis, normalized to $100 \mathrm{wt}$ \%, ** data from [15]. Notes: bdl = below the detection limit, n.a. = not analyzed. Formulae coefficients are calculated for $\mathrm{S}+\mathrm{Se}+\mathrm{Te}=2$ in melonite, frohbergite, mattagamite, and bohdanowiczite, for $\mathrm{S}+\mathrm{Se}+\mathrm{Te}=1$ in altaite and clausthalite, for $\mathrm{Te}+\mathrm{Se}+\mathrm{S}=3$ in kawazulite and skippenite, for Te $+\mathrm{Se}=3$ in tellurobimuthite, and for $\mathrm{Te}+\mathrm{Se}=4$ in sylvanite, rucklidgeite, and poubaite.

Frohbergite occurs as irregular grains up to $0.1 \mathrm{~mm}$ in dolomite. Frohbergite replaces chalcopyrite, and, in turn, is replaced by altaite (Figure 6) and by kawazulite. Frohbergite contains some impurities of $\mathrm{Se}, \mathrm{Bi}$, and $\mathrm{Ag}$ (Table 2).

Altaite forms irregular grains up to $0.5 \mathrm{~mm}$, occurs in cleavage fractures in dolomite as a chain of tiny grains, and, similar to melonite, develops along cleavage in molybden- 
ite. Altaite crystallized later than melonite and frohbergite, and replaced these minerals (Figure 6). Bigger grains of altaite contain inclusions of melonite, frohbergite (Figure 6C), and mattagamite (Figure 7). Altaite contains Se up to $2.85 \mathrm{wt} . \%$, and some Bi, Ni, and $\mathrm{Fe}$ (Table 2).
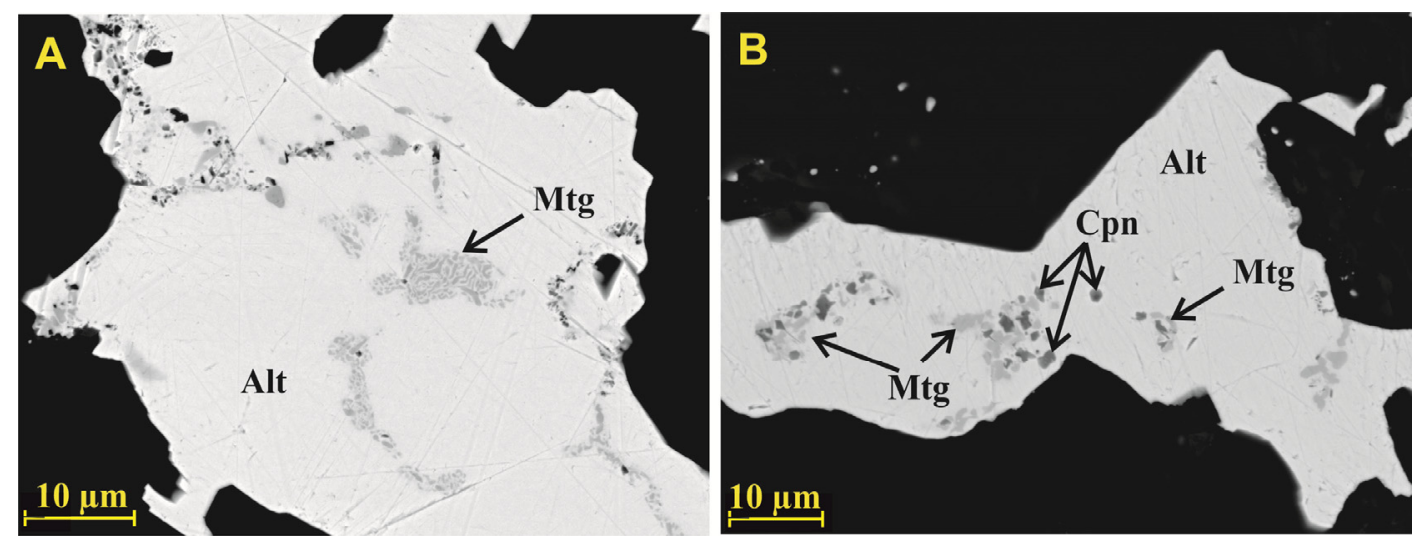

Figure 7. Mattagamite (A) and mattagamite-cobaltian pentlandite (B) inclusions in altaite. BSE images. Alt-altaite, Cpn-cobaltian pentlandite, Mtg-mattagamite.

Native gold occurs in association with altaite or with altaite and melonite: altaite overgrows gold grains (Figure 6). Size of gold grains is $<30 \mu \mathrm{m}$, gold is of high fineness, with $\mathrm{Ag} 5.00-5.75 \%$ and impurities of $\mathrm{Ni}$ and Fe.

Mattagamite, together with cobaltian pentlandite, occur in the central part of large altaite grains, where it forms clusters and chains of micro-grains $1-2 \mu \mathrm{m}$ in size (Figure 7). Estimation of chemical composition of mattagamite shows significant content of Fe (Table 2).

Finding of tellurium analogue of bambollaite was reported by Chernyavsky [16]. This mineral phase occurs as an isolated grain of $0.25 \mu \mathrm{m}$ in a cluster of melonite and altaite grains in dolomite. Chemical composition of the mineral phase is $\mathrm{Cu} 18.06$, Te 75.37, and Se 3.23, total $96.66 \mathrm{wt} . \%$. Tellurium dominates in the anion group of the studied mineral, and the formulae is $\mathrm{Cu}_{0.900}\left(\mathrm{Te}_{1.871} \mathrm{Se}_{0.129}\right)_{2.000}$ [16].

Bismuth tellurides rucklidgeite and tsumoite occur mainly in multimineral aggregates with melonite, altaite, poubaite, and clausthalite. They form irregular grains $<10 \mu \mathrm{m}$. Composition of the tsumoites corresponds to the formulas: $1: \mathrm{Bi}_{1.110}\left(\mathrm{Te}_{0.948} \mathrm{Se}_{0.052}\right)_{1.000}$, and 2: $\mathrm{Bi}_{1.066}\left(\mathrm{Te}_{0.959} \mathrm{Se}_{0.041}\right)_{1.000}$ [16]. The rucklidgeite contains high $\mathrm{Pb}$ and $\mathrm{Se}$, and its composition varies within a wide range: $1: \mathrm{Pb}_{1.428} \mathrm{Bi}_{2.220}\left(\mathrm{Te}_{3.097} \mathrm{Se}_{0.903}\right)_{4.000}$, and 2: $\left(\mathrm{Pb}_{0.580} \mathrm{Fe}_{0.043}\right) \mathrm{Bi}_{2.213}\left(\mathrm{Te}_{3.617} \mathrm{Se}_{0.383}\right)_{4.000}$. Tellurobismuthite was detected in an aggregate with altaite (Figure 8B).

Sylvanite occurs as micrometric $(1-3 \mu \mathrm{m})$ roundish grains along the boundary of two dolomite grains [16]. The sylvanite contains $2.44 \mathrm{wt} . \% \mathrm{Cu}$, which replaces Ag.

Stuetzite was detected as a cluster of irregular grains up to $10 \mu \mathrm{m}$ in size embedded in dolomite. One of the grains is an intergrowth with altaite.

Native tellurium forms clusters of irregular grains up to $30 \mu \mathrm{m}$ in size, embedded in dolomite. The chemical composition of the mineral is Te $100 \%$. Coloradoite was detected in the outer part of one tellurium grain, and it is a roundish, tiny, $2 \mu \mathrm{m}$ grain (Figure $8 \mathrm{C}$ ). Chemical composition of the coloradoite corresponds to $\left(\mathrm{Hg}_{0.869} \mathrm{Fe}_{0.011}\right)_{0.880} \mathrm{Te}_{1.119}$. 

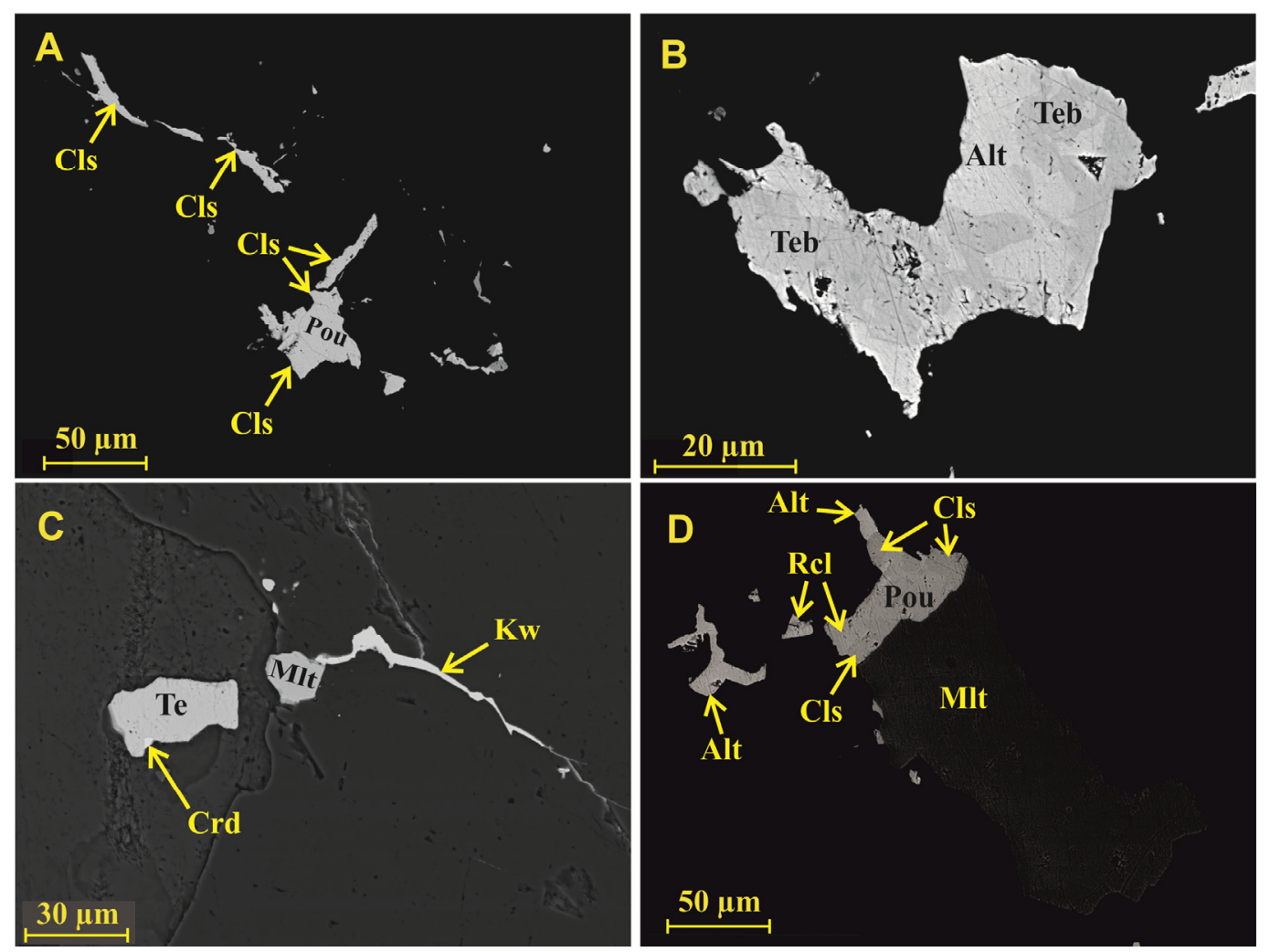

Figure 8. Tellurides and selenides in the Ozernoe occurrence. (A) Poubaite, partly replaced by clausthalite, (B) aggregate of tellurobismuthite and altaite, (C) inclusion of coloradoite in native tellurium and kawazulite veinlet in dolomite, (D) an aggregate of poubaite, rucklidgeite (a little lighter than poubaite), clausthalite (a little darker than poubaite), and altaite in the outer part of melonite grain. BSE images. Alt—altaite, Cls—clausthalite, Crd-coloradoite, Kw—kawazulite, Mlt-melonite, Pou—poubaite, Rcl—rucklidgeite, Te-native tellurium, Teb—tellurobismutite.

Poubaite was detected in a multimineral aggregate with melonite, altaite, rucklidgeite, Se-rich galena, and clausthalite (Figure 8A,D). The poubaite grains are 10-20 $\mu \mathrm{m}$ in size, anhedral. The mineral is rich in $\mathrm{Te}(\mathrm{Te}>\mathrm{Se})$, and with some excess of $(\mathrm{Bi}+\mathrm{Pb})$ compared to $(\mathrm{Te}+\mathrm{Se})$. Chernyavsky detected poubaite lamellae along cleavage in molybdenite, and chemical composition of this poubaite corresponds to $\mathrm{Pb}_{1.238} \mathrm{Bi}_{1.360}\left(\mathrm{Se}_{2.016} \mathrm{Te}_{1.847} \mathrm{As}_{0.117}\right)_{4.000}$, while arsenic content is $0.93 \mathrm{wt} . \%$ [17].

Kawazulite $\mathrm{Bi}_{2} \mathrm{SeTe}_{2}$ and skippenite $\mathrm{Bi}_{2} \mathrm{Se}_{2} \mathrm{Te}$ occur as lamellar or anhedral grains up to $0.5 \mathrm{~mm}$ in size, isolated in dolomite or in aggregates with melonite, frohbergite, altaite, and clausthalite (Figure 9). Kawazulite and skippenite replace tellurides, but in turn are replaced by clausthalite. Large anhedral grains of the minerals have internal domains, which differ in $\mathrm{Se} / \mathrm{Te}$ ratio and $\mathrm{Pb}$ content (up to $11.9 \mathrm{wt} . \%$ ). Small lamellar grains are homogenous and contain some $\mathrm{Fe}, \mathrm{Ag}$, $\mathrm{Au}$, and $\mathrm{S}$ (Table 2). Skippenite molar percentage varies from $0 \%$ to $86 \%, 70 \%$ of the studied grains are Te-dominant (kawazulite), and $30 \%$ are Se-dominant (skippenite).

Bohdanowiczite occurs in intergrowths with skippenite, and the grain is $0.3 \mathrm{~mm}$ in size (Figure 9D). The composition of the mineral shows some deficit of $\mathrm{Ag}$, partial replacement of Se by $\mathrm{Te}$, and impurities of $\mathrm{Pb}$ and $\mathrm{S}$ (Table 2).

Clausthalite is the main selenide in the Ozernoe occurrence. It occurs mostly in the outer parts of tellurides (melonite, altaite, frohbergite), selenotellurides (kawazulite, skippenite), and sulfides (pyrite, chalcopyrite) grains as a thin rim or a chain of numerous tiny idiomorphic grains (Figures 5 and $6 \mathrm{C}$ ), and penetrates bigger grains of tellurides along cracks. Clausthalite contains Te up to $3.7 \mathrm{wt} . \%$, and some impurities of $\mathrm{Bi}$ and $\mathrm{Ni}$ (Table 2). 

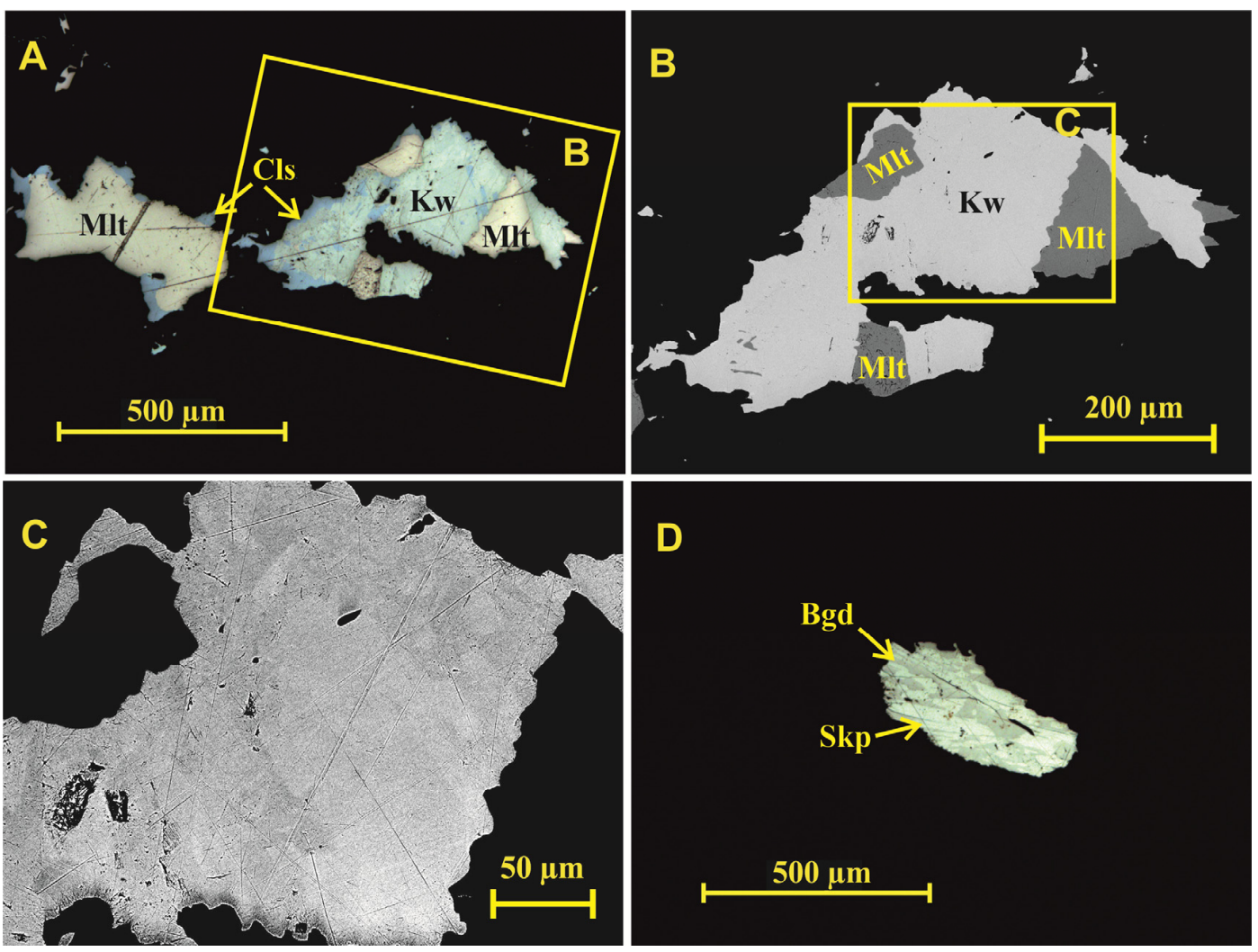

Figure 9. Kawazulite and skippenite in the Ozernoe occurrence. (A-C) Block structure in the kawazulite grain, (D) an aggregate of skippenite and bohdanowiczite. (A,D) Polished sections' photos, plane polarized light, (B,C) BSE images. Bhd—bohdanowiczite, Cls—clausthalite, $\mathrm{Kw}$-kawazulite, Mlt—melonite, Skp—skippenite.

Molybdenite is the main mineral-concentrator of selenium in the albitite uranium occurrences. Molybdenite forms flakes and aggregates of flakes, regular hexagonal crystals, and spherulites. The size of flake aggregates reaches $7-8 \mathrm{~mm}$.

Molybdenite does not associate with other sulfide minerals, but forms aggregates with melonite, and often contains inclusions of melonite, altaite, and poubaite, which may develop along cleavage as well (Figure 10C).

Table 3. Microprobe data for molybdenite from the Ozernoe and Alakurti occurrences, wt.\%.

\begin{tabular}{|c|c|c|c|c|c|c|c|c|c|c|c|c|}
\hline Point \# & 1 & 2 & 3 & 4 & $5 *$ & R-1 & R-2 & R-3 & I-1 & $\mathrm{I}-2$ & I-3 & $\mathrm{C}$ \\
\hline $\mathrm{Fe}, \mathrm{wt} . \%$ & bdl & 0.05 & bdl & bdl & 0.10 & 0.05 & bdl & bdl & 0.05 & bdl & bdl & 0.04 \\
\hline Ni, wt.\% & bdl & bdl & bdl & bdl & n.a. & n.a. & bdl & bdl & bdl & bdl & bdl & n.a. \\
\hline Mo, wt. $\%$ & 53.49 & 55.60 & 56.17 & 57.01 & 58.69 & 57.38 & 56.44 & 57.39 & 56.47 & 56.99 & 56.21 & 58.29 \\
\hline W, wt.\% & bdl & bdl & bdl & n.a. & n.a. & bdl & bdl & bdl & 0.09 & bdl & bdl & 0.09 \\
\hline Re, wt. $\%$ & bdl & 0.27 & bdl & 0.14 & 0.09 & bdl & bdl & bdl & 1.21 & 1.02 & 1.15 & bdl \\
\hline S, wt. $\%$ & 30.73 & 36.09 & 37.77 & 35.91 & 24.53 & 37.18 & 37.89 & 36.98 & 41.14 & 41.55 & 41.48 & 35.69 \\
\hline Se, wt. $\%$ & 15.71 & 8.13 & 5.84 & 6.82 & 16.58 & 5.24 & 5.38 & 5.75 & 0.33 & 0.38 & 0.86 & 5.82 \\
\hline Te, wt. $\%$ & bdl & bdl & bdl & 0.08 & n.a. & bdl & bdl & bdl & bdl & bdl & bdl & bdl \\
\hline Total, wt.\% & 99.93 & 100.14 & 99.78 & 99.96 & 100.00 & 99.85 & 99.71 & 100.11 & 99.30 & 99.94 & 99.70 & 99.92 \\
\hline \multicolumn{13}{|c|}{ Atoms per formula unit (for $\mathrm{S}+\mathrm{Se}+\mathrm{Te}=2$ ) } \\
\hline $\mathrm{Fe}$ & & 0.002 & & & 0.004 & 0.001 & & & 0.001 & & & 0.001 \\
\hline \multicolumn{13}{|l|}{$\mathrm{Ni}$} \\
\hline Mo & 0.963 & 0.944 & 0.935 & 0.985 & 1.255 & 0.976 & 0.941 & 0.976 & 0.914 & 0.914 & 0.898 & 1.024 \\
\hline $\mathrm{W}$ & & & & & & & & & 0.001 & & & 0.001 \\
\hline $\operatorname{Re}$ & & 0.002 & & 0.001 & 0.001 & & & & 0.010 & 0.008 & 0.010 & \\
\hline$S$ & 1.656 & 1.832 & 1.882 & 1.856 & 1.569 & 1.892 & 1.891 & 1.881 & 1.993 & 1.993 & 1.983 & 1.876 \\
\hline Se & 0.344 & 0.168 & 0.118 & 0.143 & 0.431 & 0.108 & 0.109 & 0.119 & 0.007 & 0.007 & 0.017 & 0.124 \\
\hline $\mathrm{Te}$ & & & & 0.001 & & & & & & & & \\
\hline
\end{tabular}

* Estimation of composition with EDS analysis, normalized to $100 \mathrm{wt} . \%$. Notes: bdl = below the detection limit, n.a. = not analyzed, numbers correspond to points in Figure 10. 

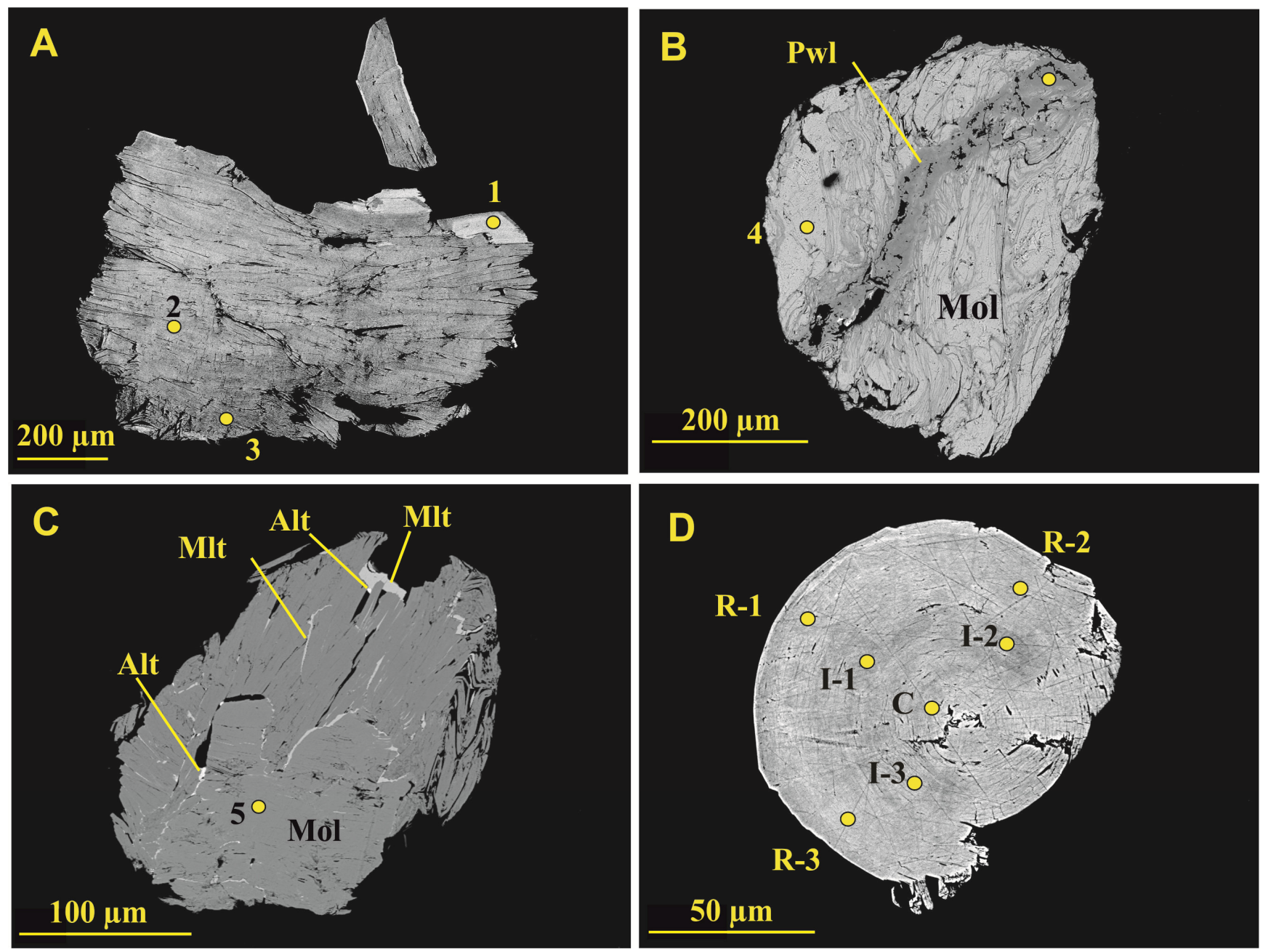

Figure 10. Molybdenite from the Ozernoe (A,B,D) and Alakurti (C) occurrences, with points of microprobe analysis (see Table 3). (A) Se-rich molybdenite in the outer part of the grain, (B) replacement of molybdenite by powellite, (C) melonite and altaite along cleavage cracks in molybdenite, and (D) a spherulite of molybdenite. BSE images. Alt—altaite, Mlt—melonite, Mol—molybdenite, Pwl—powellite.

All studied molybdenites constitute a mixture of $3 \mathrm{R}$ and $2 \mathrm{H}$ polytypes. The spherulites consist mainly of 3R polytype, but the flaky molybdenite may be 3R- or 2H-dominant [18].

Composition of the molybdenites often shows some deficit of the metal (0.88-0.98 formulae units), and molybdenite contains impurities of Fe, Re, and Se (Table 3).

Content of Re is irregular and varies significantly from one part of the grain to another. In the molybdenite flakes, Re is distributed irregularly, and no correlation of Re content and molybdenite polytype was found. In the spherulite, rhenium content is below the detection limit in the center and in the outer part, but the intermediate zone of the spherulite is anomaly Re-rich: here, Re content reaches $1.2 \mathrm{wt} . \%$ (Table 3).

All molybdenites are Se-rich. Content of selenium varies from 5 to $16 \mathrm{wt} . \%$ in molybdenite flakes (i.e., up to $17 \%$ of drysdallite), and $0.3-6 \mathrm{wt} . \%$ in spherulites. In the flakes, high selenium ( $>10 \mathrm{wt} . \%)$ was detected mainly in the outer part of the flakes, as it is shown with light colored rims of flakes in BSE images (Figure 10A). In the spherulite, the central (marked with ' $C$ ' in Figure 10D) and outer parts (' $R$ ' in Figure 10D) are enriched with Se if compared to the intermediate (' $\mathrm{I}$ ' in Figure 10D) zone (Table 3).

We showed earlier in [17] that C-parameter and volume of the crystal cell in Se-rich molybdenite increase proportionally to the increase of the selenium content.

Se- and Re-rich molybdenite was found not only in the Ozernoe, but also in dolomitealbite rock in the Alakurti occurrence (Table 3, Figure 10C). 
Molybdenite is partly replaced by powellite $\mathrm{Ca}\left(\mathrm{MoO}_{4}\right)$ and molybdomenite $\mathrm{PbSeO}_{3}$ in the zone of hyper-genesis (Figure 10B). Powellite was detected in the Ozernoe, Alakurti, and Alim-Kursujarvi occurrences. Powellite composition is (CAMECA, wt.\%): CaO 26.73, $\mathrm{MoO}_{3}$ 69.34, $\mathrm{SeO}_{3} 2.44, \mathrm{UO}_{2}$ 0.82, $\mathrm{TeO}_{3}$ 0.141, $\mathrm{SO}_{3}$ 0.132, FeO 0.107, and Re-below the detection limit, total 99.71. We see that powellite inherits partly high Se content from the mother molybdenite (6.8 wt.\% Se in the molybdenite, and $2.44 \mathrm{wt} . \%$ in the powellite) [6]. Selenium probably occupies the position of $\mathrm{Mo}^{6+}$ in powellite. Rhenium content is $0.14 \mathrm{wt} . \%$ in the mother molybdenite, and below the detection limit in the powellite, i.e., $\operatorname{Re}$ is mobilized and taken away.

\subsection{Te and Se Mineralization in Gold Deposits in Finnish Lapland}

Information about tellurium and selenium mineralization in the deposits of the Lapland belt is scant. Some tellurides were detected in the Saattopora deposit, but the mineral phases are not comprehensively characterized [1,19]. In the Pahtavaara deposit, merenskiite and clausthalite occur in quartz-carbonate-barite veins in the main mine [1], and findings of tellurides melonite, frohbergite, and hessite are reported in the VMS ore in the ore body Karolina [20]. Photographs and description of the tellurides are not available in open access.

More diversified tellurium mineralization was found in the Rompas deposit in the Peräpohja belt: the list of tellurides includes altaite [3], melonite, tellurantimony, montbrayite, frohbergite, and unnamed bismuth telluride $\mathrm{BiTe}_{2}$ [4]. The main telluride is altaite, which is detected in aggregates with native gold, hunchunite, and galena in cracks in uraninite. Other tellurides are much rarer, and a few multimineral telluride grains were found in the specimens, delivered from the Rompas to the Sankt-Petersburg University for investigation (Figure 11) [4].
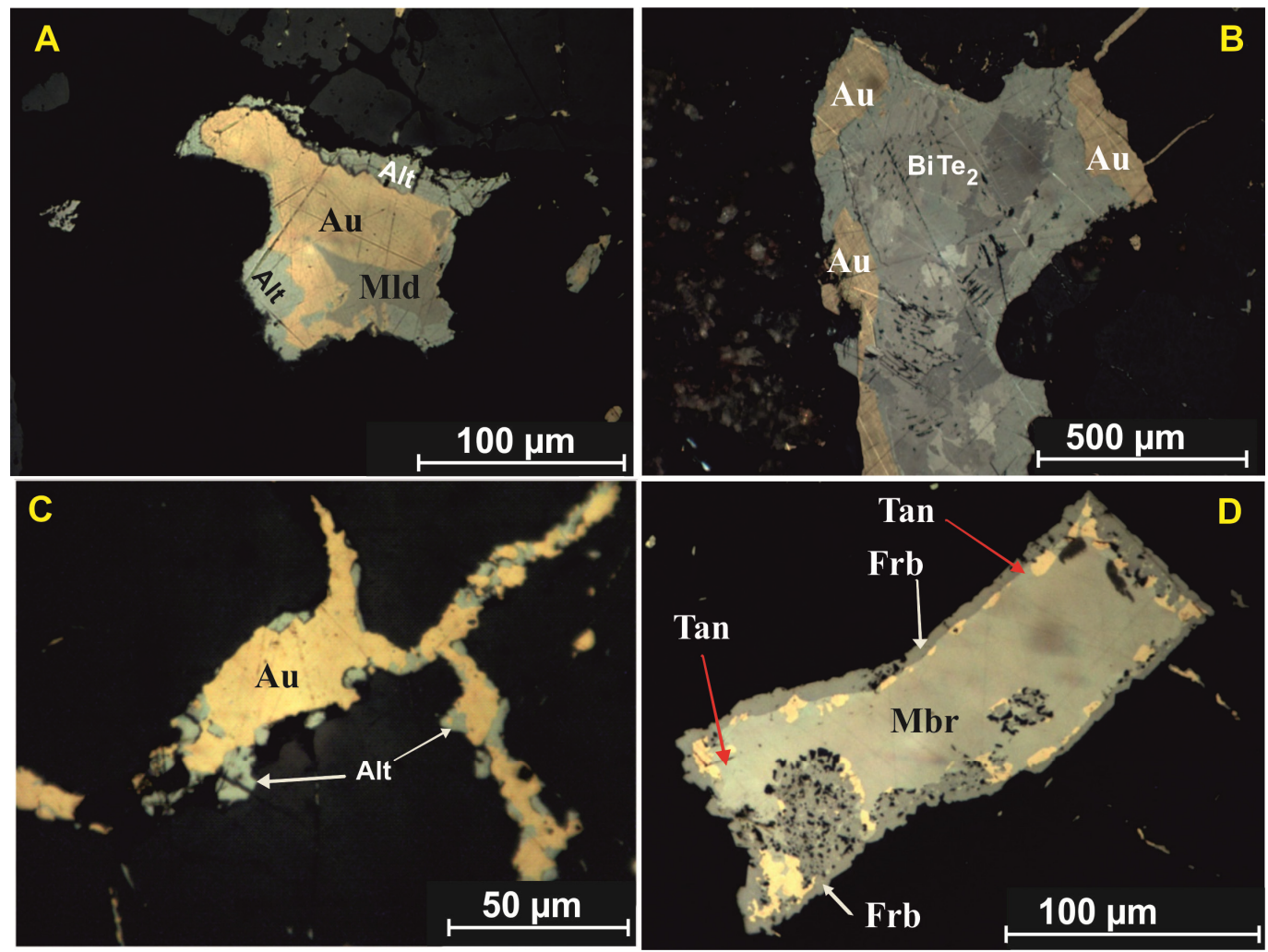

Figure 11. Telluride mineralization in the Rompas deposit, adapted after [4]. (A) Maldonite and altaite replace native gold, (B) native gold in the outer part of unnamed Bi-Te mineral phase, (C) replacement of gold by altaite, (D) zonal multimineral grain of montbrayite, tellurantimony, native gold, and frohbergite. Polished sections' photos, plane polarized light. Alt—altaite, Au—native gold, Frb—frohbergite, Mbr—montbrayite, Mld—maldonite, Tan—tellurantimony. 
The following order of crystallization of tellurides was identified in Rompas [3,4]: the early minerals are montbrayite, melonite, and bismuth telluride $\mathrm{BiTe}_{2}$, tellurantimony crystallized next, then frohbergite, and the latest was altaite. As for gold, it was repeatedly re-deposited and formed a few generations, including gold deposition at the time of crystallization of tellurides (Figure 11).

In the Kuusamo belt, according to [2,3], the Fe-Co-Au-U deposits are enriched in Te and Se, but in different ways. The Juomasuo deposit is enriched in Se, whereas the Hangaslampi deposit is anomalous in Te. The Sivakkaharju deposit is slightly enriched by $\mathrm{Te}$, and at Konttiaho, the values of Te and Se are more scattered [2].

The occurrence of tellurides is frequent in the Kuusamo belt Fe-Co-Au-U deposits [2]. Tellurides detected in every Fe-Co-Au-U deposit in the belt are altaite and calaverite. The most common telluride mineral is altaite, which occurs mostly as anhedral grains in fissures of uraninite. Altaite is also frequently recognized embedded in silicates. It is rarely developed as separate independent grains, but usually forms mixed grains with gold and other tellurides. The amount of calaverite is low, only $2-3$ grains were detected in every deposit. Melonite is almost as common as altaite (not found only in Konttiaho). It occurs principally as irregular-shaped intergrowths with gold and other tellurides such as altaite and Co-Ni telluride, but also in cracks of uraninite together with altaite. Frohbergite was detected at Hangaslampi and Juomasuo. The most common Bi-telluride is tellorobismuthite, identified at Sivakkaharju and Juomasuo. Tellurobismuthite occurs as microscopic inclusions in pyrite and as irregular grains and grain accumulations associated with altaite and gold. Mattagamite and rucklidgeite were identified at Juomasuo, and only 1-2 grains of these tellurides were found. Unnamed $\mathrm{Co}-\mathrm{Ni}$ telluride $(\mathrm{Co}, \mathrm{Ni}) \mathrm{Te}_{2}$ was detected at Konttiaho and Juomasuo; at Konttiaho, this mineral is Ni-rich compared to that at Juomasuo. Probably, these findings indicate $\mathrm{Co}-\mathrm{Ni}$ isomorphic substitution in the melonite-mattagamite system. An unnamed $\mathrm{Co}-\mathrm{Fe}-\mathrm{Pb}$ telluride was identified at Konttiaho. This $\mathrm{Co}-\mathrm{Fe}-\mathrm{Pb}$ telluride formula $\mathrm{Co}_{0.55} \mathrm{Fe}_{1.05} \mathrm{~Pb}_{0.35} \mathrm{Te}_{3.00}$ conforms to $\mathrm{Me}_{2} \mathrm{Te}_{3}$, with minor Te enrichment compared to the metals [2].

Two Se-minerals were found in the Kuusamo belt deposits [2]. Clausthalite was detected at Sivakkaharju, and kawazulite (only one grain) was identified at Juomasuo. Tiny grains $(3-15 \mu \mathrm{m})$ of clausthalite were detected in the inclusions in galena and also embedded in silicates [2]. Molybdenite is enriched with Se, especially at Sivakkaharju [2], but not as much as in Ozernoe.

\section{Discussion}

Formation of senenide and telluride minerals in sulfide ores depends mainly on fugacities of $\mathrm{Se}, \mathrm{Te}, \mathrm{S}$, and $\mathrm{O}\left(f \mathrm{Se}_{2}, f \mathrm{Te}_{2}, f \mathrm{~S}_{2}, f \mathrm{O}_{2}\right)$. The stability fields of selenide minerals are generally more restricted than those of sulfide minerals in the fugacity-fugacity diagrams, but are larger than those of corresponding telluride minerals for similar values of $f \mathrm{Se}_{2}$, $f \mathrm{Te}_{2}$, and $f \mathrm{~S}_{2}[21,22]$. However, findings of selenides in ore deposits in the world are rare compared to those of tellurides. Substantiation of this fact is in the high Se-S isomorphism as compared to Te-S due to smaller difference in ionic radius in the first pair. Consequently, selenium is often scattered in sulfides and does not form its own mineral phases.

Selenium and tellurium minerals were detected in Northern Fennoscandia in gold-only deposits (Mayskoe, Pahtavaara), gold deposit with uranium mineralization (Saattopora, Juomasuo, Konttiaho, Hangaslampi, Sivakkaharju, Rompas), and in uranium occurrences with gold (Ozernoe) (Table 4). Pahtavaara, Juomasuo, Sivakkaharju, Mayskoe, and Ozernoe contain both tellurium and selenium mineralization, while other deposits contain only tellurides.

Common features of the deposits with Se and Te mineralization in Northern Fennoscandia are their geological position in Paleoproterozoic greenstone belts, formation at the time of Svecofennian orogeny, or at post-orogenic stage [5], and geochemical association of metals, which includes $\mathrm{Au}, \mathrm{Cu}, \mathrm{Co}, \mathrm{U}, \mathrm{Bi}, \mathrm{Te}$, and $\mathrm{Se}$. 
Table 4. Te and Se minerals in the deposits of Northern Fennoscandia.

\begin{tabular}{|c|c|c|c|c|c|c|}
\hline \multirow{2}{*}{ Mineral } & \multirow{2}{*}{ Formulae * } & \multicolumn{5}{|c|}{ Deposit } \\
\hline & & Mayskoe & Ozernoe & Rompas & Kuusamo Group & Pahtavaara \\
\hline Melonite & $\mathrm{NiTe}_{2}$ & $?$ & + & + & + & + \\
\hline Frobergite & $\mathrm{FeTe}_{2}$ & & + & + & + & + \\
\hline Mattagamite & $\mathrm{CoTe}_{2}$ & & + & & + & \\
\hline Altaite & $\mathrm{PbTe}$ & + & + & + & + & \\
\hline Coloradoite & HgTe & & + & & & \\
\hline Hessite & $\mathrm{Ag}_{2} \mathrm{Te}$ & + & + & & & \\
\hline Stuetzite & $\mathrm{Ag}_{5-\mathrm{x}} \mathrm{Te}_{3}$ & + & + & & & \\
\hline Tsumoite & BiTe & + & + & & & \\
\hline Tellurobismutite & $\mathrm{Bi}_{2} \mathrm{Te}_{3}$ & + & + & & + & \\
\hline Rucklidgeite & $\mathrm{PbBi}_{2} \mathrm{Te}_{4}$ & + & + & & & \\
\hline Tellurantimony & $\mathrm{Sb}_{2} \mathrm{Te}_{3}$ & & & + & & \\
\hline Volynskite & $\mathrm{AgBiTe}_{2}$ & + & & & & \\
\hline Sylvanite & $\mathrm{AgAuTe}_{4}$ & & + & & & \\
\hline Calaverite & $\mathrm{AuTe}_{2}$ & & & & + & \\
\hline Montbrayite & $(\mathrm{Au}, \mathrm{Ag}, \mathrm{Sb}, \mathrm{Bi}, \mathrm{Pb})_{23}(\mathrm{Te}, \mathrm{Sb}, \mathrm{Bi}, \mathrm{Pb})_{38}$ & & & + & & \\
\hline Merenskyite & $\mathrm{PdTe}_{2}$ & & & & & + \\
\hline Bambollaite-Te & $\mathrm{Cu}(\mathrm{Te}, \mathrm{Se})_{2}$ & & + & & & \\
\hline Poubaite & $\mathrm{PbBi}_{2}(\mathrm{Se}, \mathrm{Te}, \mathrm{S})_{4}$ & + & + & & & \\
\hline Kawazulite & $\mathrm{Bi}_{2} \mathrm{Te}_{2} \mathrm{Se}$ & + & + & & + & \\
\hline Skippenite & $\mathrm{Bi}_{2} \mathrm{TeSe}_{2}$ & & + & & & \\
\hline Bohdanowiczite & $\mathrm{AgBiSe}_{2}$ & & + & & & \\
\hline Klockmannite & CuSe & + & & & & \\
\hline Clausthalite & $\mathrm{PbSe}$ & + & + & & + & + \\
\hline Unnamed-1 & $\mathrm{BiTe}_{2}$ & & & + & & \\
\hline Unnamed-2 & $\mathrm{Pb}_{2} \mathrm{Bi}_{2} \mathrm{Te}_{2}(\mathrm{~S}, \mathrm{Se})_{3}$ & + & & & & \\
\hline Unnamed-3 & $(\mathrm{Fe}, \mathrm{Co}, \mathrm{Pb})_{1.75} \mathrm{Te}_{3.00}$ & & & & + & \\
\hline Te native & $\mathrm{Te}$ & + & + & & & \\
\hline
\end{tabular}

${ }^{*}$ Mineral formulas according to [23].

The deposits are of different genetic groups, and classification of some of them is controversial. Saattopora is considered as an orogenic gold deposit [1,22]. In the Pahtavaara deposit, different ore bodies may be of different genesis: the mined part of the deposit with quartz-carbonate-barite veins may be classified as orogenic [5], and the ore body Karolina is probably of VMS-type [19].

Fe-Co-Au-U deposits in the Kuusamo belt were compared with orogenic deposits (with anomaly geochemical association) [14,24], IOCG [2], and Blackbird type [23], but geological characteristics of the Kuusamo deposits do not fully correspond to the mentioned genetic classes. In [23], the Juomasuo, Konttiaho, Hangaslampi, and Sivakkaharju were defined as deposits of a specific Kuusamo genetic group.

Similar intricacy concerns the gold-uranium deposits Rompas and Pajapalot in the Peräpohja belt, and these deposits were defined as the Peräpohja deposit group [25]. History of formation of Au-U mineralization in the Rompas includes a number of stages [3,26], and uraninite and native gold were repeatedly re-deposited and formed a few generations. Gold in association with tellurides was deposited after the peak of Svecofennian regional metamorphism $(\sim 1.9 \mathrm{Ga})$, and later than the formation of the youngest generation of uraninite $(\sim 1.80 \mathrm{Ga})$ and pyrobitumen nodules $[3,26]$. This is supported by the $\sim 1.75$ Ga model ages for radiogenic galena and altaite associated with gold in the late fractures in uraninite [3]. The age of tellurium and gold mineralization corresponds to the time of emplacement of late- and post-orogenic pegmatitic and tourmaline-rich granites, located $4-5 \mathrm{~km}$ to the east and north from the Rompas, between 1.80 and $1.75 \mathrm{Ga}$ [27], and these intrusions could serve as a source of both gold and tellurium. The lead for formation of altaite and hunchunite, which are localized in the fractures in uraninite, was probably mobilized from the uraninite during its recrystallization. Temperature of hydrothermal 
events at this stage was estimated as $\sim 300{ }^{\circ} \mathrm{C}$, with optical characteristics of pyrobitumen nodules in the ore [3].

Deposits and occurrences in the Russian part of the Salla-Kuolajarvi belt are not classified unequivocally. The Mayskoe deposit was considered as an orogenic deposit in [14]. However, geochronological data show that the mineralization formed 200 million years later than regional metamorphism, and a study of fluid inclusions in quartz indicates a significant role of magmatic fluids in deposit formation [8,28]. These characteristics are in conflict with the orogenic genetic model for the Mayskoe.

The study of fluid inclusions in non-mineralized quartz showed the temperature of fluid homogenization at $300-350{ }^{\circ} \mathrm{C}$, and the composition of the fluid belongs to the $\mathrm{H}_{2} \mathrm{O}-$ $\mathrm{NaCl}$ system, where the salinity is moderate, 3-7 wt.\% $\mathrm{NaCl}$-eq. In granular quartz with gold mineralization, the temperature of homogenization of fluid inclusions is $190-270{ }^{\circ} \mathrm{C}$, the fluid composition is $\mathrm{CO}_{2}-\mathrm{CH}_{4}$, the salinity of the fluid is high, $22-28 \mathrm{wt}$ \% $\mathrm{CaCl}_{2}$-eq., and is $\mathrm{CaCl}_{2}$-dominant. The pressure is estimated at $0.94-0.5 \mathrm{kbar}$ [8].

Isotope dating showed multi-stage history of mineralization development in Mayskoe. Pre-ore propylites formed at $1770 \pm 9 \mathrm{Ma}(\mathrm{Rb}-\mathrm{Sr}$, minerals and rock) [29]. Age of $\mathrm{Mg}$ metasomatism is $1610 \pm 30 \mathrm{Ma}$ ( $\mathrm{Rb}-\mathrm{Sr}$, minerals and rock) [12]. K-Ar age of feldspar in Si-K-Ba metasomatite was estimated at $1380 \pm 40 \mathrm{Ma}$ [12]. Finally, Re-Os age of gold is $397 \pm 15 \mathrm{Ma}$ [29]. The last figure should be carefully checked with some other geochronological methods, though, because mineralogical and petrographic study of mineralized rocks shows formation of gold and sulfide mineralization at the stages of $\mathrm{Mg}$ - and $\mathrm{Si}-\mathrm{K}-\mathrm{Ba}$ metasomatism [8].

A study of fluid inclusions in quartz in the Ozernoe uranium occurrence showed two groups of inclusions with temperatures of homogenization at $350-390{ }^{\circ} \mathrm{C}$ and $240-300{ }^{\circ} \mathrm{C}$. Salinity of the fluids is high, up to $22 \% \mathrm{NaCl}$-eq. [28].

Dating of albitite with U-Pb (rutile-1757 $\pm 7 \mathrm{Ma}$ ), $\mathrm{Rb}-\mathrm{Sr}$ (whole rock, apatite, biotite, albite-1754 $\pm 39 \mathrm{Ma}$ ), and Sm-Nd (whole rock, molybdenite, chalcopyrite, dolomite, albite-1759 $\pm 11 \mathrm{Ma}$ ) methods gave three well-corresponding ages of the metasomatic rock [30].This age corresponds to the age of granite dykes, $1748 \pm 13 \mathrm{Ma}$ (U-Pb, zircon),in the Salla-Kuolajarvi belt [31], and these granites could serve as a magmatic source of mineralized fluids and metals (including Se and Te) for mineralization in albitite occurrences and quartz veins in Mayskoe. Later, uraninite was re-crystallized, and chemical dating of uraninite showed $1627 \pm 42 \mathrm{Ma}$ [30]. The age of brannerite $\mathrm{UTi}_{2} \mathrm{O}_{6}(\mathrm{U}-\mathrm{Pb}$, the lower cross of the discordia) is $385 \pm 2 \mathrm{Ma}$, and this was the latest thermal event in the belt, linked with formation of ultramafic alkaline intrusions Sallanlatva and Vuorijarvi [5,32].

The mineralized albitite formed under oxidized condition, and this is supported by substitution of magnetite-pyrrhotite association in hosting amphibolites by hematite-pyrite mineral association in albitite.

$\mathrm{U}, \mathrm{Se}, \mathrm{Mo}, \mathrm{Te}, \mathrm{Re}$, and V make a geochemical group of metals, mobile under oxidized and inert under reduced conditions. This geochemical association is well-known in socalled redox roll-front uranium deposits in sedimentary rocks [33]. Hydrothermal uranium deposits and occurrences with complex Te-Se-Bi mineralization are rare in the world. These type of deposits are known in the Czech Republic (Oldrichov, the deposit of the first finding of poubaite) and in Canada (Mazenod Lake, Cluff Lake, Otish Mountains) [34]. The deposit, which displays the closest resemblance to Ozernoe, is the Otish Mountains (the deposit where Se mineral skippenite was first found [34], and molybdenite is near as rich in Se as in the Ozernoe).

Both deposits, Ozernoe and Otish Mountains, are located in the marginal part of the Paleoproterozoic greenstone belts. Uranium mineralization concentrates in the zone of hydrothermal alteration of gabbro-dolerite in the near-contact part of the intrusion, which cuts metasedimentary rocks (metasandstone and dolomite) in the Otish Mountains, and metasandstone and mafic metavolcanics in the Ozernoe. Zoning of the alteration is the following in both deposits: epidote-altered gabbrodolerite in the outer zone, chlorite- and biotite-altered rockin the intermediate zone, and albite, carbonates, and sericite are the 
main gangue minerals in the central part. Finally, uranium mineralization (brannerite and uraninite) is connected mainly with albite, and complex Bi-Pb-Cu-Fe-Mo-Te-Se-S mineralization associates with carbonates.

The general order of ore minerals' formation in the deposits with Se-Te mineralization in Northern Fennoscandia is as follows: the main sulfides pyrite, pyrrhotite, chalcopyrite, and galena were the first to crystallize, and deposition of uraninite took place later. Early tellurides crystallized after uraninite-first melonite, then frohbergite, and later altaite (and mattagamite). Early tellurides were followed by bismuth tellurides (tsumoite, rucklidgeite, tellurobismutite) and selenotellurides (kawazulite, skippenite, poubaite). Clausthalite was the latest mineral to crystallize.

The appearance of tellurides after initial deposition of sulfides reflects an increase in the $f \mathrm{Te}_{2} / f \mathrm{~S}_{2}$ ratio, most likely due to input of $\mathrm{H}_{2} \mathrm{Te}$ from a magmatic source [21].

Consecutive change of tellurides by selenotellurides and later by selenides indicates increase of selenium fugacity, $f \mathrm{Se}_{2}$, in relation to $f \mathrm{Te}_{2}$ and $f \mathrm{~S}_{2}$ [22]. Similar order of mineral formation was detected in some other deposits, e.g., in Ozernovskoe and Prasolovskoe epithermal gold deposits in Kurily islands, Russia [35].

The relatively large stability field of clausthalite in the $f \mathrm{Se}_{2}-f \mathrm{Te}_{2}$ and $f \mathrm{Se}_{2}-f \mathrm{~S}_{2}$ diagrams [21] determines clausthalite abundance in the deposits in the region and association of this selenide with tellurides of other metals.

Crystallization of molybdenite in the Ozernoe was a long process: the early molybdenite associates with melonite and altaite, which form along cleavage in molybdenite, and the late Se-rich molybdenite probably formed at the time of crystallization of selenium minerals (outer parts of molybdenite flakes are enriched with Se).

Composition of all studied selenotellurides, kawazulite-skippenite, and poubaite varies within wide limits of Se/Te ratio. Skippenite and kawazulite show the full range of miscibility (Figure 12). X-ray study of minerals with intermediate composition [10] showed homogeneity of mineral phases (no thickening or doubling of peaks in the diffractograms) and intermediate parameters of the crystal cell, which are in between kawazulite and skippenite parameters. This indicates that intermediate phases formed due to isomorphic substitution of Se and Te in the minerals, and do not constitute a mixture of kawazulite and skippenite.

Except for Se-Te substitution, the minerals of kawazulite-skippenite series contain $\mathrm{Pb}$ up to $11 \mathrm{wt} . \%$, which occupies the position of bismuth.

Substitution of $\mathrm{Co}, \mathrm{Ni}$, and $\mathrm{Fe}$ plays an important role in melonite and mattagamite. Many mattagamites from the Ozernoe and Juomasuo contain significant Fe (up to $10 \mathrm{wt} . \%$, which corresponds to 0.48 formulae units), but high Ni ( $10 \mathrm{wt} . \%, 0.48$ formulae units) was detected only in one of the studied mattagamites. High cobalt was detected in nickel telluride in the Juomasuo and Konttiaho: cobalt makes $0.24-0.49$ atoms per formulae unit in $(\mathrm{Co}, \mathrm{Ni}) \mathrm{Te}_{2}$ [2].

Absence of sulfotellurides and sulfoselenides in the deposits indicates low fugacity of $S$ at the time of crystallization of tellurides and selenides. Low sulfur activity and high activity of Se is confirmed by replacement of sulfides and tellurides by claushalite and by crystallization of Se-rich molybdenite at the late stages of the Ozernoe occurrence.

The established facts of irregular distribution of Re impurity in molybdenites and mobility of Re during molybdenite oxidation and replacement by powellite should be taken into account when molybdenites are used for geochronology (with the Re-Os method): removal of rhenium from molybdenite in the zone of weathering may result in obtaining a more ancient age of the mineralized rock. 


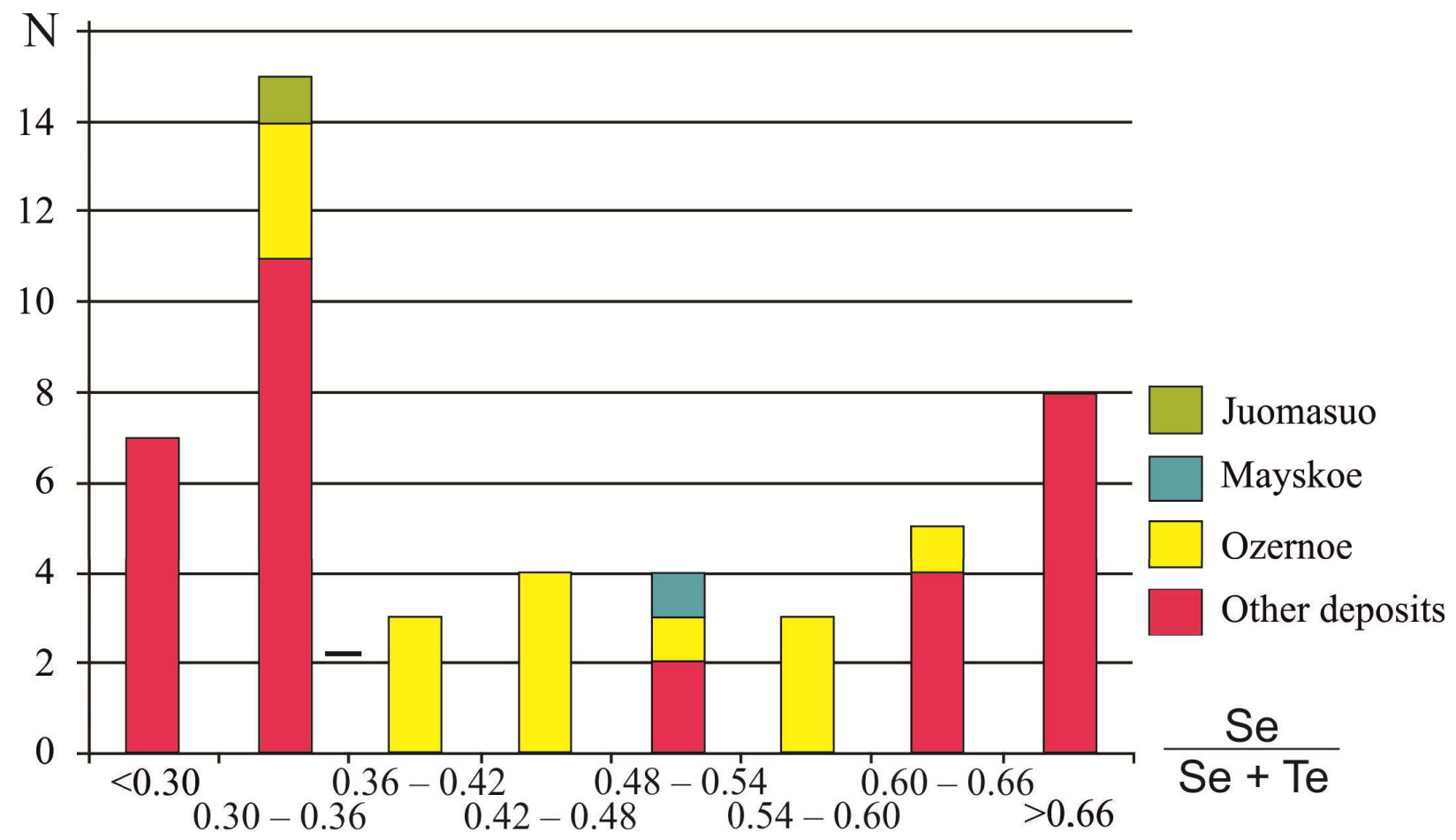

Figure 12. Histogram for composition of the minerals of kawazulite-skippenite series (in atomic \%), modified after [11], and with use of data from [2,35-40]. 0.33 corresponds to kawazulite and 0.67 toskippenite.

\section{Conclusions}

Mineralization of Te and Se was found in gold deposits and uranium occurrences, located in the Paleoproterozoic greenstone belts. The deposits are of different genesis, but all of them formed at the late stages of the Svecofennian orogeny, and they have common geochemical association of metals $\mathrm{Au}, \mathrm{Cu}, \mathrm{Co}, \mathrm{U}, \mathrm{Bi}, \mathrm{Te}$, and $\mathrm{Se}$.

In the Salla-Kuolajarvi and Perapohja belts, $\mathrm{Au}, \mathrm{Se}$, and Te mineralization formed in altered metamorphic rocks with high-temperature $\left(\sim 300^{\circ} \mathrm{C}\right)$ fluids, potentially linked with the post-Svecofennian intrusions of post-orogenic granites $(1.79-1.75 \mathrm{Ga})$. This link is supported by the data on age of Au-, Se-, andTe-mineralized rocks in the deposits. Age of mineralization in the Kuusamo belt deposits is not defined up to date, and relations of mineralization and magmatic events are not clear, which is a challenge for the future.

Findings of tellurium mineralization are much more frequent than of selenium in the region. The most diversified selenium mineralization (clausthalite, klockmannite, kawazulite, skippenite, poubaite) was discovered in the deposits located in the Russian part of the Salla-Kuolajarvi belt. Formation of telluride and/or selenide mineralization is controlled by fugacity ratios $f \mathrm{Te}_{2} / f \mathrm{~S}_{2}, f \mathrm{Se}_{2} / f \mathrm{~S}_{2}$, and $f \mathrm{Se}_{2} / f \mathrm{Te}_{2}$. Consecutive change of sulfides by tellurides, tellurides by selenotellurides, and then by selenides in the studied deposits is caused by increase of tellurium and, later, selenium fugacity in the mineralizing fluids.

In the Ozernoe uranium occurrence, the main mineral-concentrator of selenium is molybdenite, which contains up to $16 \mathrm{wt} . \%$ of Se in the marginal parts of the grains. This is the highest selenium content ever detected in molybdenite.

Funding: The work was carried out under Project 0226-2019-0053 of the Russian Academy of Science.

Data Availability Statement: The data presented in this study are available upon request from the corresponding author. 
Acknowledgments: The author thanks Yevgeny Savchenko and Yekaterina Selivanova (GI KSC RAS) for microprobe and X-ray study of minerals, and Tatiana Kaulina (GI KSC RAS) for helpful discussion of the results. The author is grateful to the Reviewers for their comments, which helped to improve the manuscript.

Conflicts of Interest: The author declares no conflict of interest.

\section{References}

1. Eilu, P.; Pankka, H. Fingold - A Public Database on Gold Deposits in Finland; Geological Survey of Finland: Espoo, Finland, 2013. Available online: http:/ / en.gtk.fi/informationservices/palvelukuvaukset/fingold.html (accessed on 21 March 2016).

2. Vanhanen, E. Geology, mineralogy and geochemistry of the Fe-Co-Au-(U) deposits in the Paleoproterozoic Kuusamo Schist Belt, north eastern Finland. Geol. Surv. Finl. Bull. 2001, 399, 229.

3. Molnár, F.; Oduro, H.; Cook, N.D.J.; Pohjolainen, E.; Takács, Á.; O’Brien, H.; Pakkanen, L.; Johanson, B.; Wirth, R. Association of gold with uraninite and pyrobitumen in the metavolcanic rock hosted hydrothermal Au-U mineralisation at Rompas, Peräpohja Schist Belt, northern Finland. Miner. Depos. 2016, 5, 681-702. [CrossRef]

4. Polekhovsky, Y.S.; Petrov, S.V.; Kalinin, A.A.; Koval, A.V. New data on mineralogy of the Rompas gold-uranium occurrence, Finland. In Trudy Fersmanovskoy Nauchnoy Sessii GI KNTs RAN (Proceedings of the Fersman Scientific Session); GI KSC RAS: Apatity, Russia, 2018; Volume 15, pp. 482-486. (In Russian) [CrossRef]

5. Kalinin, A.A. Gold in Metamorphic Complexes of the North-Eastern Part of the Fennoscandian Shield; Federal Research Centre 'Kola Science Centre': Apatity, Russia, 2018; 250p. (In Russian)

6. Gavrilenko, B.V.; Rezhenova, S.A. Ore minerals in gold-bearing quartz vein zones. In Mineral'nye Paragenezisy Metamorficheskihi Metasomaticheskih Porod (Mineral Paragenesis in Metamorphic and Metasomatic Rocks); Kola Filial AN SSSR: Apatity, Russia, 1987; pp. 58-67. (In Russian)

7. Gavrilenko, B.V. The first finding of selenides in the Kola Peninsula. Dokl. AN SSSR 1987, 296, 1213-1216. (In Russian)

8. Safonov, Y.G.; Volkov, A.V.; Vol'fson, A.A.; Genkin, A.D.; Krylova, T.L.; Chugaev, A.V. The maysk quartz gold deposit (Northern Karelia): Geological, mineralogical, and geochemical studies and some genetic problems. Geol. Ore Depos. 2003, 45, 375-394.

9. Kalinin, A.A.; Savchenko, Y.E.; Selivanova, E.A. Se and Te mineralization in abitites and perspectives for gold of the metasomatites in the Salla-Kuolajarvi belt, Northern Karelia. Dokl. Akad. Nauk. 2014, 455, 58-61. (In Russian)

10. Kalinin, A.A.; Savchenko, Y.E.; Selivanova, E.A.; Polekhovskiy, Y.S.; Zolotarev, A.A. Kawazulite $\mathrm{Bi}_{2} \mathrm{Te}_{2} \mathrm{Se}_{\text {and }} \mathrm{skippenite} \mathrm{Bi}_{2} \mathrm{TeSe}_{2}$ in albitites of the Salla-Kuolajarvi belt. Northern Karelia, Russia. Zap. RMO 2014, 2, 80-84. (In Russian)

11. Kulikov, V.S.; Kulikova, V.V. The Kuolajarvi synclinorium: A new view on the geological structure and combined cross section. In Trudy Karel'skogo Nauchnogo Tsentra RAN; Karel'skiy Nauchniy Tsentr RAN: Petrozavodsk, Russia, 2014; pp. 28-38. (In Russian)

12. Vol'fson, A.A.; Rusinov, V.L.; Krylova, T.L.; Chugaev, A.V. Metasomatic alterations in Precambrian metabasites of the SallaKuolajarvi graben near the Mayskoe gold field, Northern Karelia. Petrology 2005, 13, 161-186.

13. Kalinin, A.A.; Kazanov, O.V.; Bezrukov, V.I.; Prokofiev, V.Y. Gold prospects in the western segment of the Russian arctic: Regional metallogeny and distribution of mineralization. Minerals 2019, 9, 137. [CrossRef]

14. Ivashchenko, V.I.; Golubev, A.I. Zoloto I Platina KARELII: Formatsionno-Geneticheskie Tipy Orudeneniya I Perspektivy (Gold and Platinum in Karelia: Formational-Genetic Types of Mineralization and Prospects); Karel'skiy Nauchniy Tsentr RAN: Petrozavodsk, Russia, 2011; 369p. (In Russian)

15. Kalinin, A.A.; Karpov, S.M.; Kalachyova, A.B.; Savchenko, Y.E. New data on mineralogy of the Mayskoe gold-quartz deposit (Northern Karelia). In Trudy Fersmanovskoy Nauchnoy Sessii GI KNTs RAN (Proceedings of the Fersman Scientific Session); GI KSC RAS: Apatity, Russia, 2018; Volume 15, pp. 172-175. (In Russian)

16. Voloshin, A.V.; Karpov, S.M.; Chernyavsky, A.V. New data on minerals. The first findings in Russia and in the Kola Region. In Trudy Fersmanovskoy Nauchnoy Sessii GI KNTs RAN (Proceedings of the Fersman Scientific Session); K\&M: Apatity, Russia, 2015; Volume 12, pp. 244-250. (In Russian)

17. Voloshin, A.V.; Chernyavsky, A.V.; Bocharov, V.N.; Vasil'ev, E.A. Raman spectroscopy of the minerals of tetradymite and alexite groups. In Trudy Fersmanovskoy Nauchnoy Sessii GI KNTs RAN (Proceedings of the Fersman Scientific Session); K\&M: Apatity, Russia, 2015; Volume 12, pp. 251-255. (In Russian)

18. Kalinin, A.A.; Savchenko, Y.E.; Selivanova, E.A. Rhenium and selenium-bearing molybdenite from the Ozernoe occurrence in the Salla-Kuolajarvi belt, Northern Karelia. Zap. RMO 2013, 6, 105-115. (In Russian)

19. Saattopora Mineral Deposit Report. Geological Survey of Finland, 16 February 2018. Available online: http://tupa.gtk.fi/ karttasovellus/mdae/raportti/385_Saattopora.pdf (accessed on 20 March 2018).

20. Pahtavaara Mineral Deposit Report. Geological Survey of Finland, 16 February 2018. Available online: http://tupa.gtk.fi/ karttasovellus/mdae/raportti/376_Pahtavaara.pdf (accessed on 20 March 2018).

21. Afifi, A.M.; Kelly, W.C.; Essene, E.J. Phase relations among tellurides, sulfides, and oxides; Pt. II, Applications to telluride-bearing ore deposits. Econ. Geol. 1988, 83, 468-484. [CrossRef]

22. Simon, G.; Essene, E.J. Phase relations among tellurides, sulfides, and oxides; Pt. I, Thermodynamic properties and calculated equilibria. Econ. Geol. 1996, 91, 1183-1208. [CrossRef]

23. The New IMA List of Minerals-A Work in Progress-Updated: May 2021. Available online: http://cnmnc.main.jp/ (accessed on 4 May 2021). 
24. Sundblad, K. Metallogeny of gold in the Precambrian of Northern Europe. Econ. Geol. 2003, 98, 1271-1290. [CrossRef]

25. Eilu, P.; Rasilainen, K.; Halkoaho, T.; Huovinen, I.; Karkkainen, N.; Kontoniemi, O.; Lepisto, K.; Niiranen, T.; Sorjonen-Ward, P. Quantitative Assessment of Undiscovered Resources in Orogenic Gold Deposits in Finland; Report of Investigation 216; Geological Survey of Finland: Espoo, Finland, 2015; 318p, ISBN 978-952-217-331-7.

26. Molnár, F.; O'Brien, H.; Stein, H.; Cook, N.D.J. Geochronology of hydrothermal processes leading to the formation of the Au-U mineralization at the Rompas prospect, Peräpohja belt, Northern Finland: Application of paired U-Pb dating of uraninite and Re-Os dating of molybdenite to the identification of multiple hydrothermal events in a metamorphic terrane. Minerals 2017, 7, 171. Available online: http:/ /www.mdpi.com/journal/minerals (accessed on 20 April 2021). [CrossRef]

27. Rantaa, J.-P.; Lauri, L.S.; Hanski, E.; Huhma, H.; Lahaye, Y.; Vanhanen, E. U-Pb and Sm-Nd isotopic constraints on the evolution of the Paleoproterozoic Peräpohja Belt, northern Finland. Precambrian Res. 2015, 266, 246-259. [CrossRef]

28. Kalinin, A.A.; Prokofiev, V.Y.; Telezhkin, A.A. Composition of hydrothermal fluids of gold occurrences in the Kola region. In Proceedings of the All-Russian Conference. Physico-Chemical Factors of Rock and Ore Genesis: New Levels, Moscow, Russia, 7-9 October 2019; IGEM RAS: Moscow, Russia, 2019; pp. 74-76. Available online: http:/ /www.igem.ru/periodic/conference/ conf_19/abstracts_korzhinskiy.pdf (accessed on 20 April 2021). (In Russian)

29. Bushmin, S.A.; Belyatskiy, B.V.; Krymskiy, R.S.; Glebovitskiy, V.A.; Buyko, A.K.; Savva, E.V.; Sergeev, S.A. Isochron Re-Os age of gold from Mayskoe gold-quartz vein deposit (Northern Karelia, Baltic Shield). DAN 2013, 448, 54-57. [CrossRef]

30. Kalinin, A.A.; Kaulina, T.V.; Serov, P.A. Comparison of isotope data obtained with Sm-Nd and Re-Os methods for minerals and rocks from the Ozernoe ore occurrence, Salla-Kuolajarvi belt. Vestn. MSTU 2021, 24, 5-13. (In Russian) [CrossRef]

31. Kolyadina, A.I. Structural-Substantial Characteristics of Distribution of Gold-Uranium Mineralization in the Kuolajarvi Structure, Northern Karelia. Ph.D. Thesis, Sankt-Peterburg Mining University, S-Peterburg, Russia, 2017; 20p. (In Russian)

32. Kalinin, A.A.; Kaulina, T.V.; Lyalina, L.M.; Elizarov, D.V.; Serov, P.A. Stages in the formation of uranium mineralization in the salla-koulajarvinskaya zone (Northern Karelia): Geological and isotope geochronological data. Geol. Ore Depos. 2016, 58, 594-599. [CrossRef]

33. Bullock, L.A.; Parnell, J. Selenium and molybdenum enrichment in uranium roll-front deposits of Wyoming and Colorado, USA. J. Geochem. Explor. 2017, 180, 101-112. [CrossRef]

34. Johan, Z.; Picot, P.; Rhulmann, F. The ore mineralogy of the Otish Mountains uranium deposit, Quebec: $\mathrm{Skippenite,} \mathrm{Bi}_{2} \mathrm{Se}_{2} \mathrm{Te}_{\mathrm{P}}$ and watkinsonite $\mathrm{Cu}_{2} \mathrm{PbBi}_{4}(\mathrm{Se}, \mathrm{S})_{8}$, two new mineral species. Can. Miner. 1987, 25, 625-638.

35. Kovalenker, V.A.; Plotinskaya, O.Y. Te and Se mineralogy of Ozernovskoe and Prasolovskoe gold deposits, Kuril-Kamchatka volcanic belt. IGCP Project 486, Field Workshop 2005. Geochem. Mineral. Petrol. 2005, 43, 118-123.

36. Miller, R. Kawazulite $\mathrm{Bi}_{2} \mathrm{Te}_{2} \mathrm{Se}$, related bismuth minerals, and selenian covellite from the Northwest Territories. Can. Miner. 1981, 19, 341-348.

37. Cook, N.J.; Ciobanu, C.L. Paragenesis of Cu-Fe ores from Ocna de Fier-Dognecea (Romania), typifying fluid plume mineralization in a proximal skarn setting. Miner. Mag. 2001, 65, 351-372. [CrossRef]

38. Cook, N.J.; Ciobanu, C.L.; Wagner, T.; Stanley, C.J. Minerals of the system Bi-Te-Se-S related to the tetradymite archetype: Review of classification and compositional variation. Can. Miner. 2007, 45, 665-708. [CrossRef]

39. Dobbe, R.T.M. Tellurides, selenides and associated minerals in the Tunaberg copper deposits, SE Bergslagen, Central Sweden. Mineral. Petrol. 1991, 44, 89-106. [CrossRef]

40. Spiridonov, E.M.; Spiridonov, F.M.; Yudin, A.V. New data on skippenite $\mathrm{Bi}_{2} \mathrm{TeSe}_{2}$. Dokl. RAS 1995, 343, 229-232. (In Russian) 